\title{
Evaluacija procesa privatizacije mirovinskog sustava u Hrvatskoj
}

\section{GOJKO BEŽOVAN *}

Studijski centar socijalnog rada

Pravni fakultet Sveučilišta u Zagrebu

Zagreb, Hrvatska
Pregledni rad

UDK: 369.5:332.025.28(497.5)

doi: 10.3935/rsp.v26i1.1545

Primljeno: ožujak 2018.

Hrvatska je 2002. godine provela radikalnu reformu mirovinskog sustava privatizacijom dijela javnog sustava, takozvani II. stup definiranih doprinosa, te uvođenjem i III. dobrovoljnog stupa. Reforma je provedena po modelu Svjetske banke slično kao i u drugim tranzicijskim zemljama. Za razliku od drugih tranzicijskih zemalja, hrvatski je sustav preživio krizu i и njemu nisu poduzimane značajnije dodatne reforme.

U tekstu se tematizira korist i potreba provođenja evaluacija ovako opsežnih reformi kao razvoj politike utemeljene na dokazima. U tom kontekstu, analiziraju se mirovinske reforme u zemljama višegradske skupine (Poljska, Slovačka i Mađarska) gdje je pod utjecajem krize ukinuto obvezno članstvo u II. stupu. Glede politike mirovinskih reformi, u ovim zemljama na djelu je proces konvergencije.

Rasprave o privatizaciji mirovinskog sustava sežu u prvu polovicu 1990-ih, a uvođenjem II. stupa govorilo se o razvoju tržišta kapitala, poticanju gospodarskog razvoja, novog zapošljavanja te većih mirovina. Premda je bilo političkih planova o privremenom zaustavljanju uplata u II. stup, on je preživio krizu. Suočena s manjim mirovinama iz I. i II. stupa za dobrovoljne drugostupaše od mirovina iz I. stupa vlada je dala dodatak dragovoljnim drugostupašima koji se vraćaju u I. stup. Reformom 2018. znatan dio dodatka imaju i obvezni drugostupaši. Analiza javnog diskursa govori da su glavne dnevne novine dio medijske kampanje obveznih mirovinskih fondova $(O M F)$, zapravo društava za upravljanje mirovinskim fondovima, i u njima nema mjesta za drugačije mišljenje o II. stupu. U tekstu se analiziraju operativni troškovi društava za upravljanje OMF-ima, dominanta ulaganja u države obveznice čime se povećava javni dug te, imajući u vidu javne podatke, tranzicijski trošak.

Zaključno se vrednuju dometi mirovinske reforme s nalazima evaluacije koji ukazuju na neodrživost II. stupa te njegovu reformu kao u spomenutim tranzicijskim zemljama.

Ključne riječi: privatizacija mirovina, drugi stup, tranzicijske zemlje, Hrvatska.

* Gojko Bežovan, Studijski centar socijalnog rada, Pravni fakultet Sveučilišta u Zagrebu / Department of Social Work, Faculty of Law, University of Zagreb, Nazorova 51, 10000 Zagreb, Hrvatska / Croatia, gojko. bezovan@pravo.hr 


\section{UVOD}

Propast komunističkog poretka na europskom istoku krajem 20. stoljeća i transformacije tih društava u višestranačke demokracije s tržišnim gospodarstvima izazvali su revolucionarne promjene'. Građani i političke elite na istoku očekivali su gotove recepte sa zapada u vidu reformi koje će povećati životni standard te ojačati procese konvergencije prema Europskoj uniji (Havel, 1994.). Osnaženi građani trebali su steći slobodu i kontrolu nad svojim životima.

Glede reformi, dvojbe su postojale između postepenih reformi i šok terapija te primjerene uloge države ( Barr i Harbison, 1994.: 5-6). Promjene na tržištu - privatizacija tvrtki u državnom vlasništvu i višestranačka demokracija zahtijevale su velike promjene glede političkih $\mathrm{i}$ upravnih institucija. U tom kontekstu, naslovljavaju se i pitanja održivosti mirovinskog sustava generacijske solidarnosti te izazovi privatizacije ovog sustava po obrascu provedenom u zemljama Latinske Amerike (Barr, 1994.: 208-218). N. Barr upozorava da privatizacija mirovina zahtijeva odgovarajući regulatorni režim koji ne postoji u tranzicijskim zemljama.

Privatizacija mirovina u 1990-im značila je transformaciju države naglašavajući preokret od socijalne zaštite prema tržišno upravljanoj zaštiti rizika (Datz i Dancsi, 2013.).

Privatizacija mirovinskog sustava u Poljskoj bila je dio šok terapije vlade 1991. godine. Prijedlog nije usvojen dijelom i zbog činjenice što je tada predstavnik Svjetske banke u Poljskoj bio N. Barr, istaknuti protivnik privatizacije mirovina (Orenstein, 2009.: 133). Doživljaj ovih nastojanja Barr je vidio kao borbu protiv pretjeranog optimizma, u odnosu na ono što se može učiniti i u kojim rokovima (2002.: 357).
Evaluacija procesa privatizacije mirovina u Hrvatskoj stavlja se kao žuran zahtjev, a to je sastavni dio reformi socijalne politike u razvijenim zemljama. Kao poželjno komparativno iskustvo analizira se proces privatizacije reformi u drugim tranzicijskim zemljama koje su provele reforme po istom modelu. Rezultati istraživanja, posebno u zemljama višegradske skupine, govore o konvergencijskim procesima glede odustajanja od privatizacije mirovinskih sustava. Ističu se primjeri Poljske, Mađarske i Slovačke te se analiziraju njihovi razlozi ukidanja obveznosti II. stupa koji mogu biti poticaj za analize, rasprave i donošenje održivih odluka u Hrvatskoj.

Ciljevi i proces privatizacije hrvatskog mirovinskog sustava do sada nisu bili temeljito istraživani. Za odgovarajuću evaluaciju ovog procesa, a posebno učinaka reforme nedostaju bitni empirijski podaci koji su u vlasništvu državnih institucija i obveznih mirovinskih fondova. $\mathrm{U}$ tom smislu, ovo se istraživanje temelji na raspoloživim, javno dostupnim podacima te na intervjuima s predstavnicima relevantnih dionika mirovinskog sustava ${ }^{2}$. Dio istraživanja odnosi se na analizu javnog diskursa glede privatizacije mirovina. Zbog nedostatka empirijske građe dio ishoda evaluacije dobro su utemeljene hipoteze i aproksimacije koje bi dodatno trebalo provjeriti. To se prije svega odnosi na gubitke supstance u dioničkom portfelju obveznih mirovinskih fondova (OMF), gubitke kod dragovoljnih drugostupaša koji se vraćaju u I. stup te umirovljenika s beneficiranim mirovinama kao i na precizan izračun tranzicijskog troška.

Na kraju se izlažu ključni problemi oblikovanja, procesa i dijelom učinaka privatizacije hrvatskog mirovinskog sustava koji nije u vlasništvu domaćih dionika, a što se objašnjava teorijom ovisnosti u prijeđenom putu. O evaluaciji učinaka i ishoda više se

\footnotetext{
${ }^{2}$ Zbog osjetljivosti teme i pozicije stručnjaka u državnim institucijama ostalo se kod iskaza u samo jednom intervjuu. U metodološkom smislu, ovaj rad ima obilježje akcijski orijentiranog istraživanja u kojem je autor sudionik procesa koji analizira.

${ }^{1}$ Autor zahvaljuje trojici anonimnih kolega za korisne komentare na ranije inačice ovog teksta.
} 
zaključuje hipotetički, znači, radi se o tezama koje bi trebalo značajnim dijelom još empirijski potkrijepiti. Aproksimativnom računicom tranzicijskog troška ukazuje se na nužnost reforme II. stupa.

\section{OKVIR PRIPREME I PROVOĐENJA REFORMI TE KORIST EVALUACIJA}

Socijalne reforme trebaju snažnu političku podršku iskazivanu kroz političku volju u parlamentu, kao i podršku u javnosti. Veća politička podrška socijalnim reformama u parlamentu može jamčiti i stabilnost reformi neovisno o promjeni vlade. Reforme ne završavaju usvajanjem zakona, već postoji potreba monitoringa i evaluacije kako bi se prilagođavale novonastalim okolnostima te kako bi se sustavno preispitivalo ostvarivanje postavljenih ciljeva. Temeljni problemi i kontraverze glede evaluacije socijalnih programa tiču se paradigme, mjerenja, provedbe te problema korištenja rezultata (Chambers, Wedel, Rodwell, 1992.: 16-26). S druge strane, četiri su svrhe zbog kojih se poduzimaju evaluacije: povećanje znanja, poboljšanje isporuka u programu, revidiranje usmjerenosti programa i polaganje računa (eng. accountability) (Vedung, 2000.). Evaluacija je izvjesna socijalna intervencija pa se u opsežnim projektima postavlja pitanje o prikladnosti interne ili eksterne evaluacije. Različiti tipovi evaluacija povezuju se uz vrijeme u kojem se evaluacija provodu, pa se u tom smislu koriste ex ante evaluacije, mid-term evaluacije, evaluacije procesa i evaluacije učinka.

Evaluacije kao instrumenti u socijalnoj politici povezani su uz razvoj politike ute- meljene na dokazima (eng. evidence-based policy) što znači da postoji veća potreba da se zna što se radi, a što ne radi (Greve, 2017.). Imajući u vidu raspoloživa znanja i dokaze, danas se evaluacije sve više rade unaprijed ex ante. Evaluacije reformi velikih razmjera u javnom sektoru podrazumijevaju opsežne organizacijske pripreme i uključenost relevantnih dionika (Balle Hasen et al., 2017.). Reforme pred evaluatore postavljaju različite izazove, a ističe se različit kontekst u kojem se evaluacije provode - realnost se mijenja u odnosu na plan provedbe.

U hrvatskoj socijalnoj politici evaluacije tek dolaze na dnevni red procesom pridruživanja i sada članstvom u Europskoj uniji. Takvi su poticaji urodili i izvjesnim profesionalnim inicijativama za međunarodnim umrežavanjem te stjecanjem relevantnih kompetencija učenjem iz iskustva drugih ${ }^{3}$.

Temeljna pretpostavka, pored političke volje, za procjene i evaluacije reformskih prijedloga su raspoloživa znanja te poduzetnost akademske zajednice. Kada su u pitanju prijedlozi reforme mirovinskog sustava u Hrvatskoj, treba se složiti s Potočnjakom (2014.) kako su u tom vremenu znanja o mirovinskim reformama bila skromna.

Odbijanje reforme po modelu Svjetske banke (World Bank, 1994.) u Češkoj i Sloveniji, Cerami (2006.) dovodi u vezu s raspoloživim znanjima o ovom problemu te s kompetencijama Vlade i drugih relevantnih dionika, osobito sindikata. Kao argument za odbijanje reformi navođen je i problem pokrivanja tranzicijskog troška ${ }^{4}$. Stanovnik (2000.) navodi kako su slovenski stručnjaci za socijalnu sigurnost bili protiv uvođenja

\footnotetext{
${ }^{3}$ Do sada su uglavnom evaluatori bili strani stručnjaci i domaće konzalting tvrtke, s malo upliva relevantnog akademskog sektora. Na razini pojedinih projekata, evaluacije se ponavljaju stidljivo, više uslijed mogućnosti njihovog financiranja nego razvijenih evaluacijskih kapaciteta (Baturina, 2016.). Odnedavno djeluje Hrvatska evaluatorska mreža (dio Mreže evaluatora zapadnog Balkana - WBEN) te organizira edukacije i konferencije, a očekuje se i jačanje evaluacijske prakse.

${ }^{4}$ Reformu po modelu Svjetske banke odbila je Srbija koristeći iskustva spomenutih zemalja i inzistirajući na činjenici nemogućnosti pokrivanja tranzicijskog troška (Matković, 2016.)
} 
II. stupa. Napravljene su procjene koje su »(...) pokazale da bi uvođenje II. stupa ozbiljno pogoršalo položaj slovenskih javnih financija« (335).

U tim su zemljama postojala izvjesna znanja, s kapacitetima ex ante evaluacije, koje nije mogla dovesti u pitanje politička volja vlade, a njima su očito bili poznati i stavovi autoriteta o neodrživosti modela privatizacije mirovina u Čileu (Esping-Andersen, 1999.: 176) koje je Svjetska banka isticala kao primjer. Naivnim su kvalificirani prijedlozi Međunarodnog monetarnog fonda razvijenim socijalnim državama za privatizacijom mirovina ${ }^{5}$.

Ključne činjenice evaluacije kao sustavnog istraživanja odnose se na vrijednosnu utemeljenost te na kriterije temeljem kojih se rade procjene procesa $i$ ishoda socijalnih reformi (Stockmann, 2011.).

Glede vrijednosne utemeljenosti i kriterija za procjenu hrvatske privatizacije mirovinskog sustava oslonac se stavlja na programske, konceptualne i analitičke radove koji su upozoravali na rizike provedbe takvih reformi. Upozorava se i na tekstove koji zagovaraju provedene reforme.

Privatizacija mirovinskih sustava u tranzicijskim zemljama projekt je Svjetske banke temeljem ideologije »washingtonskog konsenzusa « koji zagovara slabljenje uloge države i jačanje tržišta u području socijalne sigurnosti. Suprotno privatizaciji mirovina i trostupnom sustavu, s tim da se mirovine iz I. stupa smanjuju na razinu socijalne pomoći, obveznog II. privatnog stupa te III. dobrovoljnog stupa, zemlje Europske unije opredijelile su se za parametarsku reformu (Cousins, 2005.). Mjere parametarske reforme računale su s povećanjem stope zaposlenosti, povećanjem dobi za odlazak u mirovinu, smanjenjem prijevremenog umirovljenja, smanjenjem razine mirovina i njihovo vezanje uz visinu uplaćenih doprinosa te ukidanjem posebnih povlastica. U tom je kontekstu bio važan stav Europske komisije o neizvedivosti privatizacije mirovina, temeljem ekspertnog istraživanja gdje se očekuje da koristi nadmaše tranzicijski trošak (European Commission, 2001.).

Kad su već reforme krenule, Svjetska banka pod vodstvom glavnog ekonomista, nobelovca Stiglitza, dijelom mijenja svoju liberalnu ortodoksiju glede privatizacije mirovina i ruši neke uvriježene mitove koji su bili temelj reformi u tranzicijskim zemljama (Orszag i Stiglitz, 1999.).

Ključni argumenti, vrijednosna polazišta i kriteriji za procjenu procesa i dijelom učinaka privatizacije hrvatskog mirovinskog sustava, nalaze se u tekstu Nicholasa Barra (2002.) ${ }^{6}$. Barr ističe kako se mirovinski sustavi suočavaju s rizicima i neizvjesnostima te ističe da je u slučaju rizika moguće poznavati ili evaluirati potencijalne posljedice dok to nije moguće u slučaju neizvjesnosti. Barr ističe tri neizvjesnosti: makroekonomske šokove koji imaju negativne posljedice na sve mirovinske sustave, demografske šokove te političke rizike (344). Pored ovih šokova, privatni mirovinski sustavi financirani kapitalizacijom suočavaju se s dodatnim rizicima. Rizici upravljanja koji su povezani s neznanjem ili zloporabama,

\footnotetext{
${ }^{5} \mathrm{Ni}$ jedna zapadna zemlja nije privatizirala dio I. stupa po analogiji tranzicijskih zemalja na način da dotadašnju stopu doprinosa za I. stup smanji i dio usmjeri u II. stup. To bi napravilo veliki manjak u I. stupu i proračunske rashode po toj osnovi s nepovoljnim utjecajem na proračunski manjak i javni dug, a time i na kreditni rejting zemlje i gospodarski rast.

Reforma koja je dijelom slična modelu tranzicijskih država provedena je u Švedskoj. Međutim, oni su uveli skroman II. stup (2,5\% bruto plaće), ali zbog toga nisu smanjivali stopu doprinosa za I. stup, već su povećali ukupnu stopu doprinosa.

${ }^{6}$ Tekst je preveden na hrvatski jezik, Barr, N. (2002.) Mirovinske reforme: mitovi, istine i strategijski izbori, Revija za socijalnu politiku, (9)3-4: 343-364. Pojam uncertainty preveden je kao nesigurnost, međutim, u ovom kontekstu bolje bi odgovarao prijevod neizvjesnost.
} 
jer korisnici nisu informirani te ne mogu imati učinkovit nadzor. Rizik investiranja - mirovinska štednja uložena na burzovna tržišta izložena je fluktuacijama. U pogledu vrijednosti štednje-mirovine prisutan je i element hazarda. Rizik tržišta u odnosu na rente - vrijednost rente $u$ odnosu na štednju ovisi o očekivanom trajanju života te stopi prinosa koji se osiguranjem može očekivati za to razdoblje.

Barr u privatiziranom sustavu mirovina ističe i problem nedovoljno informiranih korisnika osiguranja. Naime, privatne su mirovine kompleksne jer se zasnivaju na mnoštvu institucija i instrumenata.

Posebno važan dio Barrove analize su mitovi o mirovinama koji imaju obmanjujuće učinke. Deset mitova on dijeli u tri skupine: makroekonomika mirovina, elaboracija mirovinskih sustava te uloga Vlade. Za potrebe ove analize ističu se oni mitovi koji imaju veću relevantnost u analizi privatizacije hrvatskog mirovinskog sustava.

Barr dovodi u pitanje mit da kapitalizacija rješava problem nepovoljne demografije te zaključuje da demografske promjene nisu dovoljan argument za prelazak na kapitalizaciju.

Mit o postojanju neposredne veze između kapitalizacije i rasta predmet je kontraverzi. Naime, radi se o samo jednom izvoru rasta. Ako kapitalizacija i povećava rast, ona nužno ne povećava dobrobit, a može imati i različite međugeneracijske redistributivne učinke.

Da kapitalizacija u II. stupu smanjuje javne mirovinske troškove neodrživ je mit jer, ako javni sustav nije održiv, jedino je rješenje učiniti ga održivim. To se postiže povećanjem doprinosa, smanjivanjem naknada ili kombinacijom tih dviju mjera.

Neodrživ je i mit da mirovine financirane kapitalizacijom diversificiraju rizike jer se ne mogu nositi s upravljačkim rizicima, gdje upravljanje može biti pošteno, a nekompetentno. Postoji investicijski rizik koji se često zanemaruje.

Barr se kritički osvrće na ključni pristup reformi mirovinskog sustava: »(...) mirovinski sustavi imaju tri cilja: borbu protiv siromaštva, ravnomjerno usklađivanje potrošnje i osiguranje. Racionalna politika počinje definiranjem ciljeva i nastavlja se raspravom o instrumentima radi ostvarenja tih ciljeva. Problem analize Svjetske banke je u tome da njezina klasifikacija polazi od instrumenata, a ne ciljeva, te da ona $u$ određenoj mjeri prejudicira izbor, a također i kombinaciju instrumenata« (2002.: 357).

S izvjesnim odmakom i uvidom u rezultate reformi u tranzicijskim zemljama Barr (2013.) ističe pitanja tranzicijskog troška, troška upravljanja te kapaciteta za provedbu reformi. Posebno se ističe činjenica troškova upravljanja. Naime, ako je taj trošak $1 \%$ tijekom 40 godina, on smanjuje akumulaciju na pojedinom računa člana za skoro $20 \%$.

Zagovornici privatizacije mirovina više se oslanjaju na radove Roberta Holzmanna nego na N. Barra. Holzmann ne dovodi u pitanje reformske korake poduzete u programu Svjetske banke kako bi se postigla fiskalna održivost i primjerenost mirovina, a Barr i Diamond (2009.) nekompletnom drže analizu Holzmanna i Hinza iz 2005. godine, napravljenu za Svjetsku banku. ${ }^{7}$

\footnotetext{
${ }^{7}$ Više vidjeti Holzmann, MacKellar i Repansek (eds.) (2009.) i Holzmann i Guven (2009). Potonju studiju koja se bavi analizom primjerenosti mirovina poslije reformi u središnjim, istočnim i južnoeuropskim zemljama potaknula je i sufinancirala ERSTE zaklada iz Beča. ERSTE zaklada ovim je projektom uložila u prihode svog zakladnika ERSTE banke koja od privatiziranih mirovinskih sustava ostvaruje znatnu dobit. U Hrvatskoj djeluje Erste plavi obvezni i dobrovoljni mirovinski fond.
} 


\section{PRIVATIZACIJA MIROVINSKIH SUSTAVA U TRANZICIJSKIM ZEMLJAMA}

Prilikom rasprava i uvođenja privatizacije mirovinskih sustava u tranzicijskim zemljama prevladavali su više emocionalni od znanstvenih pristupa (Bielawska, Chłoń-Domińczak i Stańko, 2015.). Primjerice, za razliku od Mađarske, u Poljskoj je postojalo veće političko suglasje o uvođenju ove radikalne reforme. $\mathrm{Na}$ reformu u Poljskoj gledalo se kao na proces modernizacije, pozapadnjenja i bijega iz zagrljaja komunizma.

Krajem 1990-ih mirovinski sustavi u zemljama srednje i istočne Europe bili su neodrživi zbog starenja stanovništva, nasljedstva $\mathrm{PAYG}^{8}$ sustava iz socijalističkog razdoblja osjetljivog na političke pritiske. K tome, prijevremena umirovljenja, izberivost za invalidske mirovine te velikodušna indeksacija mirovina uz pad zaposlenosti povećali su stopu ovisnosti. Kao rezultat ovih faktora javni mirovinski sustav bio je neodrživ, s velikim implicitnim mirovinskim dugom, (Velculescuova, 2011.: 3). Analizirajući neizvjesnost mirovinskih reformi u tranzicijskim zemljama, Velculescuova (2011.: 4-5) naglašava da se od reformi očekivalo poboljšanje dugoročne fiskalne održivosti, osiguranje diversifikacije rizika te doprinos dodatnim makroekonomskim koristima.

U skladu s očekivanjima, tranzicijski se trošak pojavljuje kao ključni sporni čimbenik privatizacije mirovinskog sustava. On je rizik za javne financije i zbog toga ovu reformu nisu prihvatili Slovenci (Stanovnik, 2000.). Taj trošak nastaje uplaćivanjem dijela doprinosa u II. stup, a to je manjak za potrebe tekućih umirovljenika. On se povećava razmjerno povećanju broja osiguranika u II. stupu, a počinje se smanjivati kada se u I. stupu počinju ostvarivati osnovne mirovine koje su u prosjeku manje od mirovina iz jednodijelnog sustava ${ }^{9}$. Tranzicijski trošak traje čak, u smanjenim iznosima, do 70-80 godina, odnosno sve dok je živ posljednji umirovljenik kojem je mirovina utvrđena temeljem staža prije uvođenja II. stupa. Tranzicijskom trošku treba pribrojiti početne troškove reforme, kamate koje država plaća na državne obveznice te operativne troškove poslovanja društava za upravljanje obveznim mirovinskim fondovima.

Tranzicijski trošak znatno se razlikuje po zemljama, a najveći je u Poljskoj (16\% BDP-a), koja izdvaja 19,5\% za doprinose, a od toga 7,3\% za privatni II. stup (Bielawska, Chłoń-Domińczak i Stańko, 2015.: 17). Pored plana da se tranzicijski trošak financira jednim dijelom privatizacijom državnih poduzeća on se u cijelosti financirao emitiranjem javnog duga, a tome kao trošak treba pribrojiti kamate. Plan je bio da se tranzicijski trošak aktualan u razdoblju 50-60 godina pokrije privatizacijom državne imovine tijekom 13 godina. Računica pokazuje da se ovim pokrilo samo pet od pedeset godina gubitaka. Kako bi se pokrila rupa u javnim financijama uzrokovana izdvajanjima u II. stup, Vlada se 1999. godine trebala zadužiti za $0,3 \%$ BDP-a, a 2008. godine za $1,5 \%$ BDP-a (Fultz, 2012.).

Krajem 2010. godine tranzicijski je trošak bio oko jedne trećine ukupnog javnog duga. Ministarstvo financija izračunalo je 2013. godine da, ako bi se gubitak doprinosa usmjerenih OMF-ima u cijelosti financirao javnim dugom, to bi dosegnulo iznos od 112\% BDP-a (Szczepański, 2016.).

\footnotetext{
${ }^{8}$ Eng. pay-as-you-go (plati kako stigne) je drugi izraz za model međugeneracijske solidarnosti ili tekuće raspodjele.

${ }^{9}$ To su bile okosnice analize tranzicijskog troška u Strategiji razvitka mirovinskog sustava i sustava socijalne skrbi (NN, 97/2003.).
} 
K tome, u Poljskoj su službene osobe (vojska, policija..) izašle 2003. iz II. i vratile se u I. stup koji je ustrojen po NDC načelima ${ }^{10}$, a poljoprivrednici nikada nisu ušli u II. stup (Galinowska i Žukowski, 2011.).

Okidač za rasprave o učinkovitosti mirovinskih reformi bila je kriza 2008. godine i izvjesna ograničenja proračunskog manjka. Do tada su privatizirani mirovinski fondovi $74,9 \%$ kapitala uložili u državne obveznice, $21,5 \%$ u dionice, a $2,5 \%$ u novčane depozite (Bielawska, Chłoń-Domińczak i Stańko, 2015.: 24). Poljska je manje bila izložena krizi, a 2009. imala je rast BDP-a od 1,7\%, a 2010. 3,8\% (Galinowska i Žukowski, 2011.). K tome, proračunski manjak 2009. bio je $7,4 \%$. Kriza je utjecala na rast nezaposlenosti, a kriza tržišta kapitala imala je izrazito negativne utjecaje na otvorene mirovinske fondove.

Već 2004. godine na dnevni red javnih rasprava došla je tema upravljačkih troškova obveznih mirovinskih fondova. Prema visokim naknadama bila je kritična Vlada, a posebno ministrica rada i socijalne politike (Galinowska i Žukowski, 2011.), a sve veći broj članova iskazivao je nepovjerenje prema otvorenim mirovinskim fondovima. Postavljano je javno pitanje zašto mirovinska društva računaju tako velike troškove upravljanja za kupnju dominantno državnih obveznica. Kao rezultat uvida i pritisaka, to je postalo političko pitanje uz kampanju koju je vodila Gazeta Wyborcza, troškovi su upravljanja 2010. prepolovljeni sa $7 \%$ na $3,5 \%$. Računajući troškove, uložena sredstva i povrat, poljski su fondovi u prvih šest godina proizvodili gubitke (Fultz, 2012.).

Rast javnog duga počeo se približavati ustavnom ograničenju od 60\% BDP-a, plan približavanja euro zoni značio je smanjenje deficita ispod 3\%. S druge strane, Europska komisija je subvencije OMF-a držala elementom javnog duga, a ne ulaganjem $u$ buduće mirovine. Na stolu je bila odluka o rezanju mirovina ili opcije povećanja dobi umirovljenja, ograničavanje subvencija za mirovinsko osiguranje poljoprivrednika i smanjenja doprinosa u II. stup (Fultz, 2012.).

U takvim okolnostima ministar financija J. Rostowski predložio je smanjenje doprinosa za II. stup sa $7,3 \%$ na $2,3 \%$ te člankom koji je objavio u Gazeti Wyborc$z i$ otvorio veliku javnu raspravu. $\mathrm{U}$ članku kaže da su OMF-i »(...) rak mirovinskog sustava, koji sada napada javne financije« te bezdana vreća, zlatna koka bankara. Tranzicijski trošak smanjio je ulaganja u infrastrukturu i obrazovanje (Naczyk, 2016.). S druge strane, L. Balcerowicz bio je protiv smanjenja doprinosa za II. stup te je zagovarao rezanje socijalnih troškova i ubrzanje procesa privatizacije. Javni diskurs o ovoj temi bio je obilježen i televizijskom raspravom u najgledanijem terminu Rostowskog i Balcerowicz kao arhitekta ove reforme (Fultz, 2012.) $)^{11}$.

Živa se rasprava vodila između oponenata i zagovornika II. stupa. Raniji zagovornici reforme ministarstvo rada, ministarstvo financija, mirovinski zavod, sindikati i stručnjaci za socijalnu politiku okrenuli su se protiv II. stupa, a s druge strane bio je jaki financijski lobi (Ingolt, 2016.: 246).

Na stranu vlade stao je predsjednik Narodne banke Poljske i raniji premijer M. Belka pozivajući se na socijalno-tržišno gospodarstvo kao na ustavnu kategoriju. Njegovi su argumenti bili da mirovinski

\footnotetext{
${ }^{10}$ Nominalni sustav određenih doprinosa NDC (eng. notional defined contribution), a više o NDC sustavu vidjeti u Vukorepa (2012.: 161-164).

${ }^{11} \mathrm{O}$ ovoj temi raspravljao se i u utjecajnom Financial Time, a naslovi i sadržaj tekstova izražavali su interese utjecajnih financijskih krugova (R. Atkins, Poland plays with fire over pension reform, https://www.ft.com/ content/ac8221f4-88e3-11e3-9f48-00144feab7de, posjećeno 25.10.2017.).
} 
sustav nije osigurao primjerene mirovine te da funkcionirajući na trošak sadašnje generacije dovodi u pitanje solidarnost (Galinowska i Žukowski, 2011.).

Predloženo smanjenje doprinosa u II. stup provela je 2011. godine vlada D. Tuska te su nastavljene rasprave o održivosti mirovinskog sustava. Vlada je napravila projekcije da je time do 2020. smanjila zaduživanje za 69 milijardi USD, a do 2060. za 272 milijarde USD (Fultz, 2012.). Bio je izazov kako se nositi s »dvostrukim-manjkom« (eng. double-deficit) koji proizlazi iz neravnoteže financiranja tekućeg sustava i predfinanciranja reforme (Galinowska i Žukowski, 2011.: 283). To znači, mirovine se isplaćuju na račun javnog duga u I. stupu, a javni je dug kao »imovina na osobnim računima u II. stupu. Vlada je evaluirala učinkovitost ulaganja OMF-a, a rezultati su evaluacije dodatno narušili ugled OMF-a. Udruga OMF-a govorila je o nacionalizaciji mirovinskih računa te su organizirali nacionalnu medijsku kampanju za obranu II. stupa, a njihov zahtjev nije uvažio niti ustavni sud ${ }^{12}$. Ista je vlada 2013. učinila II. stup dobrovoljnim i transferirala je sve državne obveznice OMF-a u instituciju socijalne sigurnosti, zabranjujući dobrovoljnim fondovima da u buduće ulažu u državne vrijednosnice (Naczyk, 2016.). Broj članova u II. stupu pao je sa 16 na samo 2,6 milijuna koji uplaćuju 2,92\% doprinosa (Krzyzak, 2017.). Kao izvjesnu kompenzaciju vlada je povećala porezne poticaje za štednju u III. stupu.

Donesena je i odluka 2013. godine kojom se postepeno povećava dob za umirovljenje muškaraca sa 65 i žena sa 60 godina na 67 godina. To je trebalo povoljno utjecati na financijsko stanje Zavoda za mirovinsko osiguranje. Demografski procesi dovode u pitanje dugoročnu održivost mirovinskog sustava. Dok je 2013. na 1000 radno aktivnih stanovnika bilo 295 umirovljenika, 2060. bit će ih 786. Očekuje se kako će aktivna obiteljska politika, posebno promicana u mandatu D. Tuska, doprinijeti ublažavanju negativnih demografskih trendova (Szczepański, 2016.; Ingolt, 2016.).

U Mađarskoj privatizaciju mirovinskog sustava na političku agendu stavio je ministar financija Lajos Bokros ${ }^{13}$, inače zagovornik liberalne ekonomije, 1995. godine (Naczyk, 2016.). Privatizacija mirovinskog sustava u Mađarskoj 1997. godine uvedena je pod devizom da se time smanjuju buduće financijske obveze vlade te da se potiče rast (Müller 1999.; Simonovits, 2011.a). U javnosti se više vjerovalo u privatno nego u javno, bio to mirovinski, obrazovni, zdravstveni ili transportni sustav (Simonovits, 2011.a). Parametarska reforma 1997. podrazumijevala je povećanje dobi za odlazak u mirovinu muškaraca sa 60 na 62 godine do 2001., a žena s 55 na 62 do 2008. godine. Desna stranka FIDEZ Viktora Orbana nije podržala u parlamentu ovu reformu, a njihovim dolaskom na vlast 1998. reforma se usporava i ne provodi planirano povećanje doprinosa za II. stup sa $6 \%$ na $8 \%$. Naglašavajući gospodarski patriotizam, Orban je kritizirao privatizaciju mirovina. U međuvremenu je nova vlada povećala izdvajanja u II. stup na $8 \%$, a 24\% išlo je u I. stup (Naczyk i Domonkos, 2016.).

Ključno pitanje bio je tranzicijski trošak kojem se na početku posvećivalo malo pozornosti ili ga se ignoriralo, da bi projekcije pokazale da će većina onih koji će primati mirovinu iz I. i II. stupa do 2050. godine imati manju mirovinu nego da su ostali u prvom stupu (Simonovits, 2011.a).

Ponovnim dolaskom na vlast 2010., uz dvotrećinsku većinu u parlamentu, a s nasljeđem gospodarske i proračunske krize

\footnotetext{
${ }^{12}$ Ovakvu argumentaciju navodi Vukorepa (2018.), a ne pitajući se za odgovornost vlade za održivost II. supa, prije svega visine tranzicijskog troška.

${ }^{13}$ Bokros je došao u Hrvatsku za savjetnika vlade I. Račana, a u programu Svjetske banke.
} 
od 2006. godine, Orbanov ministar financija predlaže preusmjerenje doprinosa iz II. stupa u javni mirovinski sustav kako bi se smanjili proračunski manjak i javni dug. Prijedlog je bio u studenom 2010. zaustaviti uplatu doprinosa u II. stup na 14 mjeseci, a da bi u prosincu 2011. bila donesena odluka o ukidanju II. stupa Fultz (2012.). U doba međunarodne financijske krize OMF-i su pretrpjeli strašne gubitke. S druge strane, Europska komisija nije Mađarskoj dala povlastice, kojima bi se predfinanciranje računalo kao ulaganje u buduće mirovine, pa je tranzicijski trošak za II. stup računala kao dio proračunskog manjka i javnog duga. Kako bi opravdao vladinu odluku, Orban je govorio da nitko ne može prisiliti građane da svoju ušteđevinu stave na rulet (eng. roulette table), igre na sreću, a da im nitko ne jamči isplatu minimalne vrijednosti mirovine. S druge strane, Orban je ograničio djelokrug odlučivanja ustavnog suda pa isti nije više mogao odlučivati o mogućoj žalbi OMF-u (Simonovits, 2011.b).

Nacionalizirani kapital OMF-a $(9 \%$ BDP-a) bio je korišten za smanjenje proračunskog manjka $(5 \%)$ te za plaćanje radikalnog rezanja poreza na dohodak $(4 \%$ BDP-a) kroz tri godine (Simonovits, 2011.a). Ovakva radikalna odluka podsjeća E. Fultz (2012.: 17) na odluku koju je Argentina donijela 2008. godine, a kada OMF-i nisu mogli prodati državne obveznice kako bi isplatili mirovine. Uloga javnosti i javnih rasprava prije reforme $\mathrm{i}$ prilikom ukidanja II. stupa u Mađarskoj bila je znatno manja nego u Poljskoj.

Sličan primjer privatizacije mirovina, a potom ukidanja obveznosti II. stupa slijedio je u Slovačkoj (Naczyk i Domonkos, 2016.: 178-179). Na temu mirovinskog sustava u doba krize i održivosti II. stupa vlada R. Fice sazvala je 2009. međunarodnu konferenciju. Ishodi konferencije potaknuli su dijalog s predstavnicima Svjetske banke. U Slovačkoj je II. stup ostao dobrovoljan, a premijer R. Fico drži da je on bio nepovoljan za dvije trećine članova koji su imali niže dohotke (Krzyzak, 2015.). Slovačka je 2008. kao otklon od liberalizacije javnih financija u II. stupu ukinula obvezno članstvo, a 2012. smanjila doprinose s $9 \%$ na $4 \%$. Premijer Fico nije htio povećati PDV kako bi financirao tranzicijski trošak i time zaduživanje zemlje. Zbog iskustva manjih mirovina iz I. i II. stupa u odnosu na potencijalne mirovine samo iz I. stupa u Slovačkoj sve veći broj članova istupa iz II. stupa (Krzyzak, 2015.a).

U smislu izloženih slučajeva o privatizaciji mirovinskih sustava zaključuje se da su u zemljama višegradske skupine na djelu procesi konvergencije (Schneider, 2012.), koji se ne dovode u pitanje niti u novijim raspravama.

Transnacionalnu kampanju za privatizaciju mirovina početkom 2000-ih zbog konceptualnih čimbenika pomela je globalna financijska kriza. Razmjeri gospodarskog kolapsa 2008. - 2010. promijenili su stavove javnosti i elita širom svijeta prema izglednosti financijskih tržišta kao alternative mirovinama koje daje država. Posebno se to vidjelo i na gubitcima američkih privatnih mirovinskih fondova (Orenstein, 2013.). U tim okolnostima dolazi do idejne (eng. ideational) promjene glede privatizacije mirovina u stavovima Svjetske banke i Međunarodnog monetarnog fonda.

Dakle, fiskalna i idejna objašnjenja objašnjavaju dijelom pad nove mirovinske paradigme. Ako se gleda fiskalni dio, onda se može zaključiti da će se vlade ponovno vratiti privatizaciji mirovina ako ozdrave financije. S druge strane, gledajući idejne čimbenike, može se zaključiti da neće doći do povratka na privatizaciju, već će se računati na promjene koje su se dogodile u međunarodnom diskursu. Pojavljujući trendovi govore o kombinaciji jednog i drugog, kontinuirani fiskalni pritisak na državu može držati novu mirovinsku paradigmu iznad vode, ali sa supstancijalnim promjenama prvog i drugog reda za postavke i 
instrumente politike. Eksperti su naučili iz iskustva da postoje značajni problemi i ograničenja glede privatizacije mirovina. Visoki troškovi upravljanja pojeli su novce s individualnih računa, a tranzicijski troškovi u cjelini bili su pretjerano opterećenje. Zemlje sa slabim financijskim tržištem nisu u stanju dobro rukovoditi privatizacijom mirovina (Orenstein, 2013.).

Promjene prvog i drugog reda, kao odgovore na rastuće izazove mirovinskih sustava, poslije financijske krize govore o evoluciji mirovinske paradigme. Promjene prvog reda stavljaju na dnevni red uspostavu minimalnih mirovina, a promjene drugog reda zagovaraju dobrovoljnu štednju koju ce poticati vlade. Promjene drugoga reda u međunarodnim raspravama povećale su interes za nominalni sustav određenih doprinosa (NDC) koji ima kapacitet kreiranja mirovina bez velikog tranzicijskog troška i velikih upravljačkih troškova (Orenstein, 2013.). NDC je inačica državno upravljanog sustava međugeneracijske solidarnosti utemeljenog na individualnim računima.

Analize pokazuju, posebno u slučajevima Poljske, Mađarske i Slovačke, kao i kod drugih zemalja koje su rezale sustav privatiziranih mirovina, da je globalna financijska kriza bila okidač, ali ne i glavni uzrok. Pojavljivanjem financijske krize drugi su stupovi iskusili poteškoće zbog tri nedostatka u njihovom oblikovanju. Drugi stup financiran je preusmjerenim doprinosima iz javnog mirovinskog sustava i to stvara veliku i nepremostivu rupu u financiranju javnog mirovinskog sustava. Za popunjenje rupe Vlada se mora zaduživati. Drugo, II. stup stvorio je produljenu nesigurnost glede računanja, isplate i usklađivanja mirovina tijekom vremena. Treće, ograničena regulacija glede troškova upravljanja OMF-ima dala im je mogućnost uzimanja velike sume novaca s računa članova (Fultz, 2012.). Sličnu argumentaciju o greškama mirovinskih reformi izvode Adascalitei i Domonkos
(2018.: 49). Naime, fiskalni tereti prebacivanja dijela doprinosa na privatne račune bili su podcijenjeni. Privatizacija mirovina provedena je bez temeljne regulatorne i financijske infrastrukture. Drugo, time su izostali učinci privatnog stupa na tržišta kapitala, na gospodarski rast i na slabu zaštitu malih dioničara. Treće, upravljački i marketinški troškovi bili su previsoki, a kompeticija među OMF-ima nije vodila smanjenju upravljačkih naknada, a s druge strane faza isplate mirovina ostala je slabo regulirana. Dakle, nedostaci u oblikovanju i ishodima reformi bili su ključni razlozi odustajanja od njihove provedbe.

Studija Međunarodne organizacije rada (Ortiz, Durán-Valverde, Urban i Wodsak, 2018.) analizira privatizaciju javnog mirovinskog sustava u trideset zemalja širom svijeta po modelu Svjetske banke te zaključuje da se radi o neuspjelom projektu koji nije doprinio održivosti mirovinskih sustava. Visoki tranzicijski troškovi negativno su utjecali na javne financije. Visoki troškovi upravljanja značili su manje prinose obveznih mirovinskih fondova i time manje mirovine. Osiguranici - vlasnici uplaćenih doprinosa u obveznim mirovinskim fondovima isključeni su iz upravljanja, a država nije ostvarila odgovarajući nadzor nad privatizacijom javnog novca. Zaključuje se kako je korist od privatizacije javnih mirovinskih sustava izvukao samo financijski sektor. Ovaj se projekt naziva privatizacijskim eksperimentom i preporuča se ukidanje privatiziranog II. stupa.

\section{PRIVATIZACIJA MIROVINSKOG SUSTAVA U HRVATSKOJ}

\section{Oblikovanje reforme}

Ovaj dio teksta, nastojeći rekonstruirati kronologiju reforme, bavi se analizom relevantnih rasprava, dokumenata i radova glede pripreme, donošenja odluka i provede reforme. 
Prve rasprave o privatizaciji, slično kao i ostalim tranzicijskim zemljama, bile su više emotivnog nego znanstvenog karaktera. Štoviše, u Hrvatskoj su bili na djelu izljevi neupitne opredijeljenosti za žurnom privatizacijom $^{14}$. Pozivalo se na primjer američkog mirovinskog investicijskog fonda Fidelity koji je osnovan 1946. i do danas odlično funkcionira, s godišnjim rastom između 10\% i 15\% (Njavro, 1994.: 33). Oduševljeno se govorilo o čileanskom modelu: »(..) dok sustav kapitalnog pokrića koji sam malo prije spomenuo u jednom Čileu, koji je čak uveden u za vrijeme totalitarizma u toj državi, odlično funkcionira« (Brčić, 1994.: 60). Drugi stručnjak ističe: »Čileanci su uspjeli smanjiti stope doprinosa i tako ojačati akumulativnu i reproduktivnu sposobnost čileanskog gospodarstva, a s druge strane uspjeli su povećati svotu mirovina čak na sedamdeset posto od posljednje plaće, naglašavam, sedamdeset posto od posljednje plaće, što zapravo znači da čileanski umirovljenici zadržavaju potpuno istu razinu standarda, ili relativno potpuno istu, kakvu su imali za vrijeme aktivnog radnog vijeka« (Škember, 1994.: 65). Škemberov je prijedlog bio da »(...) treba zadržati, koliko je god moguće, ono što dobro funkcionira, ili relativno dobro, pa i slabije, nego se upustiti u avanturu a da prethodno nismo napravili makar neke simulacije da li će to funkcionirati. Dakle, bio bih u ovom trenutku za to da se model generacijske solidarnosti sačuva, a da se uz taj model generacijske solidarnosti uvedu neki dodatni izvori financiranja koji neće opterećivati gospodarstvo« (1994.: 70).
Strani su stručnjaci na konferenciji u kraćim izlaganjima upozoravali na činjenicu »(...) da nismo vidjeli niti jednu osobu koja je prošla kroz taj sustav, počevši od zaposlenja do mirovine « (Queisser, 1994.: 171), pa se nije moglo govoriti o uspjesima čileanskog modela. Pored toga, Queisser (1994.: 118-126) govori o problemu tranzicijskog troška, visokim troškovima upravljanja sustavom, neupućenim građanima i nedostatku tržišta kapitala u Čileu. Heubeck (1994.: 169) ističe da se model privatizacije mirovina u Hrvatskoj ne može provesti sve dok ne postoji privatno gospodarstvo i poduzeća koja mogu dati dividende na dionice. Heubeck traži jasnu sliku, procjenu budućih godina glede izdataka za različite mirovine: »(...) a bez takve osnove svaka promjena nekog sustava, svaka reforma lebdi u zraku« (1994.: 69).

Emotivan ${ }^{15}$ i konfuzan pristup domaćih sudionika konferencije vidljivo se razlikovao od analitičkog i odmjerenog pristupa stranih stručnjaka. Iz fonograma konferencije vidi se da domaći stručnjaci nisu bili upućeni u temu te da nisu bili sugovornici stranim kolegama.

U ovom dijelu analizira se proces reforme i privatizacija mirovinskog sustava. Do 1998. godine u Hrvatskoj je održano deset rasprava o reformi mirovinskog sustava ${ }^{16}$, a kao naročito relevantnu raspravu, okrugli stol, Hrvatska mirovinska reforma: izazovi novog sustava na tri oslonca, 1998. godine organizirao je Centar za industrijsku demokraciju Saveza samostalnih sindikata Hrvatske $^{17}$.

\footnotetext{
${ }^{14}$ Kao empirijska građa ovdje je poslužio fonogram konferencije »Preobrazba socijalnog osiguranja u uvjetima slobodnog tržišnog gospodarstva: nužnost preobrazbe mirovinskog osiguranja«. Konferencija je održana 10.-11. prosinca 1994. u Zagrebu, a u organizaciji Ministarstva rada i socijalne skrbi i Republičkog fonda mirovinskog i invalidskog osiguranja radnika Hrvatske. Na konferenciji su govorili potpredsjednik vlade, ministri, stručnjaci, dio akademske zajednice te inozemni stručnjaci.

${ }^{15} \mathrm{Iz}$ fonograma rasprave može se rekonstruirati ozračje optimizma koje je vladalo na konferenciji. Očito je privatizacija bila panacea i, u ovom slučaju, pridruživanje neupitno uspješnom projektu.

${ }^{16} \mathrm{Na}$ ovu činjenicu upozorio je u raspravi I. Bulaš (1998.).

${ }^{17}$ Teze za raspravu, nekoliko izlaganja te rasprava s okruglog stola objavljeni su u Reviji za socijalnu politiku, br. 2-3, 1998. Autorizirane rasprave važna su podloga ove analize.
} 
Uvodnim izlaganjima, spomenutog okruglog stola, problematizira se radikalni pravac reformi, po konceptu Svjetske banke, koji označava privatizaciju mirovina na osnovi kapitalizirane štednje te redukciju prvog stupa javnih mirovina gotovo do rezidualne razine (Puljiz, 1998.). Ukazuje se i na problem visokog tranzicijskog troška, a dovodi se u pitanje teza da kapitalizacija dugoročno ima pozitivne efekte na štednju. Utjecaj reforme na rast nacionalne štednje kao i na njezinu upotrebu u svrhu ubrzanog gospodarskog rasta te pokrivanje tranzicijskog troška dovodi u pitanje i Zdunić (1998: 136.). Puljiz napominje: »Ovaj oprez pred kapitalizacijom ne znači da taj model, posebno u prikladnoj kombinaciji s PAYG-sustavom, treba odbaciti. No, pogrešno je euforično ga prihvaćati kao definitivno pronađenu mirovinsku formulu koja je istovremeno motor gospodarskog razvoja « (1998.: 128). U tezama za raspravu zaključuje se: »Naime, nije sporno da bi djelomičnu kapitalizaciju mirovina trebalo uvesti, ali je pitanje kada i kako to učiniti. Mi mislimo da je u sadašnjem trenutku uvođenje drugog stupa iz više razloga u nas preuranjeno i nedovoljno pripremljeno. Bolje je koncentrirati pažnju na solidnu izgradnju promijenjenog prvog te uvođenje trećeg mirovinskog stupa oko čega, osim u pogledu pojedinih rješenja, ne postoji temeljnih sporova« Puljiz (1998.: 128). Kritikama uvođenja drugog stupa pridružio se i Škember (1998.: 144) te ističe nedostatak rasprava o toj temi, upozorava na tranzicijski trošak, na nestabilno gospodarstvo, na nerazvijeno tržište kapitala, a problem vidi i u upravljanju budućim mirovinskim fondovima.

Rasprava na okruglom stolu posebno je istaknula pitanje neodrživosti tranzicijskog troška. H. Kraljevićc ${ }^{18}$ (1998.: 156) ističe:
»Iz Prijedloga zakona sasvim je nejasan tranzicijski trošak reforme, a također i ukupno opterećenje državnog proračuna. Posebno ističem da bi donošenje ovog zakona, uz taj nedostatak, bilo suprotno Ustavu. U obrazloženju zakona naveden je tranzicijski trošak u grafičkom obliku tijekom sljedećih 35 godina, a isti grafikon nalazi se i u tekstu vladinog Povjerenstva za mirovinsku reformu. Vjerodostojnost tog grafikona za mene je krajnje dvojbena. Prema tom grafikonu, u početku trošak iznosi oko $2 \%$ BDP-a i smanjuje se tijekom 10 godina na nulu, a nakon dvadesete godine opet je u porastu, što je potpuno apsurdno. Vjerujem da je prikazani grafikon rezultat neke simulacije koju je provela Svjetska banka, ali osnovano sumnjam $\mathrm{u}$ ispravnost mnoštva ulaznih podataka potrebnih za takvu simulaciju (napokon, omjer izdvajanja u prvi i drugi stup nije fiksiran, pa je izračunavanje tranzicijskog troška nemoguće; također, sasvim je nejasno koliki se BDP uzima u svakoj od sljedećih 35 godina i tko je izradio studiju na osnovi koje je taj procijenjen). Napokon, za tako krupnu reformu ne bismo se smjeli do kraja i bez vlastite provjere pouzdati $\mathrm{u}$ podatke koje dobijemo od Svjetske banke; interes banke vjerojatno se ne podudara s interesom naše države. Nužno bi bilo provesti temeljitu analizu i izračunavanje ne samo tranzicijskog troška nego i ukupnog opterećenja proračuna na temelju preciznih podataka o sadašnjem stanju kao i na temelju demografskih i razvojnih projekcija. To je krajnje složen račun, ali u Hrvatskoj ima stručnjaka koji to mogu provesti ukoliko imaju pristup pravim podacima. Moja je procjena da je za taj posao potrebno barem 3 mjeseca, ali ne više od pola godine«. Kraljević se založio i za javnu raspravu, posebno onih koji su stručni i koji razumiju

${ }^{18}$ Kraljević, profesor na matematičkom odsjeku Prirodoslovno-matematičkog fakulteta Sveučilišta u Zagrebu, u to doba bio je saborski zastupnik. 
temu, a ne da Svjetska banka i političari donesu odluku o reformi ${ }^{19}$.

Zoran Anušićc ${ }^{20}$, predstavnik Svjetske banke na okruglom stolu, uvodna izlaganja okarakterizirao je kao kozmetički pristup, a dio dijaloga, posebno istup H. Kraljevića, kao napad na Svjetsku banku. Anušićeva (1998.) objašnjenja o pokrivanju tranzicijskog troška i povećanju nacionalne štednje s pozivanjem na primjer Čilea, gdje je stopa kapitalizacije rasla od 1981. do 1994. nevjerojatnih $13 \%$, nisu bila uvjerljiva u odnosu na postavljena pitanja.

Izlaganja i rasprava na okruglom stolu identificirali su ključne izazove pred kojima se nalazio mirovinski sustav s jasno iznesenim dvojbama i osporavanjima prijedloga koje je nudila Svjetska banka. Važno je primijetiti da se o reformi dijelom govori kao o privatizaciji sustava socijalne sigurnosti, što je dominantan analitički okvir u drugim tranzicijskim zemljama. Umjesto koncepta privatizacije ipak se više govori o drugom stupu kao kapitalizaciji mirovinske štednje. Kao kritiku treba istaknuti činjenice da se u uvodim izlaganjima, kao akademskim tekstovima, ne poziva na radove koji su se bavili privatizacijom mirovina $u$ drugim tranzicijskim zemljama.

Institut za javne financije održao je dvije rasprave o mirovinskoj reformi u kojoj je sudjelovao širok krug različitih stručnjaka. ${ }^{21}$
U tom vremenu za Hrvatsku je moglo biti relevantno slovensko iskustvo (Stanovnik, 2000.: 335) odbijanja privatizacije mirovinskog sustava ${ }^{22}$, protiv nje su slovenski stručnjaci za socijalnu sigurnost, kao i sindikati, a procjene su pokazivale da je uvođenje drugog stupa ozbiljno pogoršalo stanje javnih financija. Samodol (2000.) je upozorio na rizike reforme glede nerazvijenosti tržišta kapitala. Argumentiranu kritiku mirovinske reforme po modelu Svjetske banke iznio je A. Škember (2000.) ističući kako, kao pretpostavka, za takvu reformu treba biti razvijeno tržište kapitala, tržište vrijednosnih papira, financijsko tržište, razvijen bankarski sustav i tržište rada. Škember zaključuje kako je potrebno transparentnim učiniti tranzicijski trošak, kao i ukupno opterećenje za državni proračun.

Na kompleksnost sustava privatizacije mirovina te njegove prednosti i nedostatke upozorio je iz drugačije perspektive D. Bakić (2000.). Sustavi definiranih doprinosa jednostavniji su i transparentniji za potencijalne korisnike. Nepredvidivost i neizvjesnost budućih mirovina ovisnih o dugoročnim rezultatima investiranja vide se kao konceptualna manjkavost. Veliki je izazov utvrđivanje cijena doživotnih renti i na njega utječe više okolnosti, a to su: nepovoljan izbor - rizik odabira doživotne rente, produljenje očekivanog trajanja

\footnotetext{
${ }^{19}$ Kraljević će kao saborski zastupnik prilikom usvajanja zakona 1999. ponovno iznijeti sličan stav: »Međutim, nezadovoljni smo s upornim i teško shvatljivim odbijanjem da se u reformu uđe tek nakon temeljite analize i sagledavanja posljedica različitih varijanti tijekom sljedećih nekoliko desetljeća. Jer ovo su vrlo krupni zahvati, radi se o vrlo velikom novcu i vrlo su dugoročni i moramo biti svjesni što će se i što se sve može dogoditi. « (Hrvatski državni sabor, 1999.). Umjesto temeljite analize spominje se u raspravi marketinška studija Ekonomskog fakulteta u Zagrebu koja je trebala »opravdati« reformu.

${ }^{20}$ Ranije je bio pomoćnik ministra financija u hrvatskoj vladi. U Guardiancichevoj analizi (2007.: 91) ističe se da je pristup reformi bio elitistički i nasilan, a socijalni su partneri dijalog više doživljavali kao instrukcije, a vanjsku uvjetovanost kao diktat.

${ }^{21}$ Okrugli stol »Stanje u reformi mirovinskog sustava Hrvatske« održan je 28. rujna 2000. godine, a radovi su objavljeni u časopisu Financijska teorija i praksa 3/2000., a rad D. Bakića objavljen je u broju 2/2000. Potom je Institut 8. studenog 2001. organizirao okrugli stol »Organizacijski aspekti mirovinske reforme«, a radovi su objavljeni u istom časopisu 2/2002.

${ }^{22}$ Dakle, koristi se pojam privatizacija koji ne koriste hrvatski autori. Kod nas je skovan i pojam mirovinske reforme na tri oslonca.
} 
života, inflacija te visoki administrativni troškovi ${ }^{23}$.

Izlaganje K. Múller (2002.) na drugom skupu po usmjerenosti i referencama razlikuje se od hrvatskih autora i posebno se ističe uloga države u privatizaciji (ponovno termin privatizacija) mirovinskog sustava. Posebno se ističe rizik financiranja tranzicijskog troška i ulaganje znatnog portfelja privatnih mirovinskih fondova u državne obveznice. To se, uz nerazvijeno tržište kapitala, ističu kao razlozi odbijanja privatizacije mirovinskog sustava u Sloveniji i Češkoj. Múllerova zaključuje kako u privatizaciji mirovinskog sustava nisu bitne samo sposobnosti privatnog sektora, već su podjednako važne i mogućnosti države. »Ako se nije udovoljilo minimalnim institucionalnim i organizacijskim zahtjevima koji stoje pred javnim sektorom, privatizacija mirovinskog sustava postaje vrlo opasna strategija« (2002.: 399). To autorica sažima u misao N. Barra: »Ako je država neučinkovita, u opasnosti je bilo koji mirovinski sustav«.

U međuvremenu je Svjetska banka (2000.) izdala programski dokument, znatno konkretniji od ranijih (1995., 1997.) glede provedbe privatizacije mirovinskog sustava u Hrvatskoj te je u njemu optimistično istaknuto: »(...) važno je da je Hrvatska ozakonila sve elemente mirovinske reforme koji su usporedivi s već provedenim reformama u Mađarskoj i Poljskoj, uključujući i kapitalizirani 'drugi stup'. Primijenjen na odgovarajući način, taj drugi stup ne samo što nudi izglede za bolje mirovine mlađim radnicima, već isto tako može postati pokretačem rasta, s time što će donijeti dubinu $\mathrm{i}$ istinsku konkurentnost hrvatskim tržištima kapitala« (2000.: 163).

Ovaj dokument osobito je važan jer se u njemu po prvi put hrvatskoj javnosti objašnjava kako će biti financiran tranzicijski trošak. »U načelu, učinci reforme iz 1998.-99. (parametarska reforma, op. autora) pokrit će većinu tranzicijskog troška koji se vezuje uz drugi stup, i to kroz smanjenje razine isplata mirovina iz prvog stupa, povećanje dobi za umirovljenje te iskorištavanje kratkoročnog porasta mlade radno sposobne populacije« (2000.: 164). Dakle, smanjenje mirovina iz sustava međugeneracijske solidarnosti, odnosno prvog stupa, bilo je planirano kako bi se dijelom pokrio tranzicijski trošak. Iz ranijih rasprava ne vidi se da je ovakav koncept pokrivanja dijela tranzicijskog troška bio uopće tematizi$\operatorname{ran}^{24}$. Nije jasno u kojoj su mjeri donositelji odluka bili svjesni ovih činjenica. Naime, $\mathrm{u}$ javnosti je bio sve prisutniji problem novih, koji su primali manje mirovine, i starih umirovljenika koji su imali veće mirovine. Pod tim pritiskom Vlada je, uoči izbora 2007. godine ${ }^{25}$, donijela Zakon o dodatku na mirovine ostvarene prema Zakonu o mirovinskom osiguranju, pa se korisnicima mirovina određuje, zavisno o svoti mirovine i godinama ostvarivanja prava na mirovinu, dodatak na mirovinu od $4,0 \%$ za mirovine

${ }^{23}$ Poslije će D. Bakić (2017) kao stručnjak za aktuarsku matematiku dati ostavku na članstvo u stručnoj skupini Povjerenstva za mirovinsku reformu jer predstavnici vlade nisu prihvatili traženje vremena za provedbu dodatnih analiza glede tranzicijskog troška. U provedbi reforme očita je bila dominacija političke volje u odnosu na potrebne ekspertne analize i rasprave (NN, 102/1998.).

${ }^{24}$ Očekivalo bi se da je dokument Svjetske banke, posebno glede pokrivanja tranzicijskog troška, bio temom rasprave drugog okruglog stola Instituta za javne financije u studenom 2001. godine.

${ }^{25}$ Rizik redistribucije u mirovinskom sustavu pokriven je ulogom u iste izbore, a odnosi se na Zakon o potvrđivanju ugovora između Republike Hrvatske i Bosne i Hercegovine o suradnji na području prava stradalnika rata u Bosni i Hercegovini koji su bili pripadnici Hrvatskog vijeća obrane i članova njihovih obitelji (NN, 2/2006.). Dakle, u hrvatski mirovinski sustav ušli su invalidi Hrvatskog vijeća obrane kojima su invalidske mirovine u $\mathrm{BiH}$ male, pa je odlučeno da primaju dio mirovina i od Hrvatske. Ova je skupina, zbog zaostalih isplata mirovina ponovno došla na dnevni red poslije izbora 2016. godine, a glede sastavljanja većine u Saboru. 
ostvarene u 1999. godini do 27,0\% za mirovine ostvarene u 2010. godini. Time su ozbiljno dovedeni u pitanje ciljevi reforme, odnosno privatizacije mirovina u dijelu ključnog izazova pokrivanja tranzicijskog troška. Dodatak na mirovinu bio je ranije neplanirani trošak državnog proračuna, a njegovo pokrivanje dovelo je do povećanja PDV-a na neodrživih $25 \%$.

Opozicijske stranke, osim HSS-a, nisu u Hrvatskom saboru dvojile o reformi mirovinskog sustava po konceptu Svjetske banke. Dolaskom na vlast, koalicijska Vlada donosi Strategiju razvitka mirovinskog sustava i sustava socijalne skrbi ${ }^{27} \mathrm{koja}$ prihvaća koncept Svjetske banke. Koje su bitne točke Strategije? Jasno se kaže kako ce razina mirovina iz dvodijelnog sustava u prosjeku biti manja od mirovina korisnika koji ostvaruju mirovinu samo iz prvog dijela. Međutim, »ako će realna stopa povrata biti barem jednaka ili veća od stope realnog rasta plaća, onda će, naročito za osiguranike koji će ostvarivati mirovinu nakon 2025., ukupna razina mirovine (iz prvog i drugog dijela) biti veća od mirovine koju bi ostvarili da su bili osigurani samo u prvom dijelu mirovinskog osiguranja«. S druge strane, pod utjecajem snažne marketinške kampanje ${ }^{28}$, neupućena javnost očekivala je kako se reforma poduzima kako bi mirovine bile veće.

Strategija se nešto više bavi tranzicijskim troškom i zaključuje da on bitno ovisi o načinu njegovog definiranja. Zanimljivo, strategija se ne poziva na spomenuti dokument Svjetske banke (2000.) i način fi- nanciranja tranzicijskog troška. Povezano s tim, strategija je naslovila pitanje javnog duga i relevantnu dvojbu: »Pitanje je kakve ce posljedice ovakvo kretanje javnog duga ostaviti na kreditni rejting zemlje i njenu poziciju na financijskim tržištima u smislu uvjeta zaduživanja, te njene sposobnosti da emitira tolike iznose svojih obveznica«. Uz nepovoljniju varijantu emitiranja javnih obveznica javni dug 2035. godine iznosio bi $25 \%$ BDP-a.

Troškovi poslovanja javnog mirovinskog osiguranja iznose oko 2,5\% godišnjih izdataka i postupno bi se trebali smanjivati. Strategija je procijenila troškove poslovanja u II. stupu na do $2 \%$ godišnje vrijednosti imovine mirovinskih fondova i oko $5 \%$ vrijednosti godišnjih doznaka u mirovinska osiguravajuća društva.

Postavljena su i relevantna pitanja primjene strategije, među kojima ističemo sljedeće: nedostatak sredstava za financiranje tranzicijskog troška; nerazvijenost financijskog tržišta na kojem nedostaju vrijednosnice u koje bi se ulagala imovina prikupljena u mirovinskim fondovima; nerazvijenost sustava nadzora koji mora spriječiti zloupotrebe novca namijenjenog financiranju mirovina; nedostatak znanja i kadrova sposobnih za provođenje djelomično privatiziranog mirovinskog sustava; neizvjesnost gospodarskih kretanja i brzine izlaska iz gospodarske i socijalne krize; slom financijskog tržišta; visoki troškovi provedbe privatiziranog dijela mirovinskog sustava; krajnje nepovoljna demografska kretanja i visoka razina »sive ekonomije «.

${ }^{26}$ Povećanje PDV-a na $25 \%$ ministar S. Linić branio je i isplatama mirovine uz protupitanje novinarima bi li to trebalo pokriti zaduživanjem i plaćanjem kamata od 8\%. »PDV 25\%, turizmu 10\% od iduće godine«, Novi list, 10. 2. 2012.

${ }^{27}$ To je bio dio opsežne Strategije razvitka Republike Hrvatske »Hrvatska u 21. stoljeću«, a spomenutu strategiju vlada je usvojila sredinom 2002. godine, a o njoj je potom raspravljao i Hrvatski sabor (Puljiz, 2002.). Strategija je objavljena u Narodnim novinama (NN, 97/2003.).

${ }^{28}$ Kao dio marketinške kampanje u novinama su izlazile brošure s izračunima mirovina iz II. stupa uz određena ulaganja i na određene rokove koje bi danas bilo zgodno preispitati. Anonimna sugovornica drži da su procijenjene mirovine iz II. stupa bile približno dvostruko veće od ostvarenih. Marketinška je kampanja bila agresivna i koštala je 120 milijuna kuna (Guardiancich, 2007.: 126). 
S druge strane, strategija kao dokument nije sačinjena po pravilima zanata. Naime, nisu jasno istaknuti ciljevi, indikatori, očekivani rezultati, učinci i ishodi kako bi se provela evaluacija privatizacije mirovinskog sustava. U tom smislu, postavljena relevantna pitanja mogla su se preoblikovati u izvjesne ciljeve $\mathrm{i}$ indikatore te temeljem toga obavljati sustavan i neovisan monitoring i evaluacija provedbe strategije.

Privatizacija mirovinskog sustava - II. stup, kao i mirovinske reforme u cijelosti, premda su postojali zahtjevi za dodatnim analizama, to jest, ex ante evaluacijom bio je projekt koji je oblikovala Svjetska banka.

\section{Analiza provedbe reforme}

Nakon šest godina funkcioniranja i isplate prvih mirovina iz kapitaliziranoga mirovinskog osiguranja Marušić i Škember (2008.) govore o potrebnim korekcijama određenih parametara o kojima ovisi razina mirovina i troškovi u privatiziranom mirovinskom sustavu. Autori upozoravaju na izlaganje E. Fultz iz 2006. godine da $20,6 \%$ sredstava u OMF-ima odlazi na naknade (351), a troškovi u javnom sustavu 2007. godine bili su 1,4\%. Drugo sustavno istraživanje o troškovima upravljanja I. i II. stupa ustanovilo je da je »kumulativni iznos naplaćene naknade po članu (zanimljiv svakom članu obveznog mirovinskog fonda), 2010. je iznosio 1696 kuna. Istodobno je razlika između imovine aktivnog člana i uplaćenih doprinosa po članu iznosila 4 $859 \mathrm{kn}$. Zbroje li se ta dva iznosa i promotri udio naplaćenih naknada po članu u toj sumi, vidljivo je da su OMD prosječno za sebe zadržala $26 \%$, dok je ostatak pripao članu fonda« (Bađun i Klemenčić, 2011.: 6). Ovi autori ističi da su obvezna mirovinska društva 2010. imala prihode od upravljanja
276,6 milijuna kuna, a rashode od upravljanja OMF-ima 27,6 milijuna kuna, što je deset puta više. Zaključuje se kako društva nisu koristila mogućnost propisivanja nižih naknada te da naknade za upravljanje utvrđuju u najvišem dopuštenom iznosu (2011.: 5). Škember (2017.) procjenjuje ove troškove na $16-17 \%$ uplaćenih doprinosa. Od 2002. do 2010. iznos naplaćenih naknada bio je 1,420 milijarde kuna, a ukupno uplaćeni doprinosi iznosili su 31,550 milijardi kuna. U ovom istraživanju nisu obuhvaćeni troškovi porezne uprave koja prikuplja mirovinske doprinose, kao ni troškovi mirovinskih osiguravajućih društava. Bađun i Klemenčić ističu kako fondovi, nažalost, ne koriste mogućnost snižavanja naknade za upravljanje imovinom, a naknada predstavlja najveći dio prihoda OMD-a. Ove su naknade postepeno smanjivane pa su 2011. bile $0,65 \%$, 2012., 2013., 2014. i 2015. bile su 0,45\%, a za svaku narednu godinu smanjuju se za $7 \%$, da bi 2020. dosegnule razinu od $0,3 \%{ }^{29}$.

Naime, u kontekstu ovako visokih naknada za upravljanje postavlja se pitanje njihovog ubiranja temeljem nominalne vrijednosti imovine. Cetiri mirovinska društva koja upravljaju OMF-ima u 2015. iskazali su dobit u iznosu od 192,4, a 2016. godine 182 milijuna kuna.

Marušić i Škember (2008.: 354-356), analizirajući visinu mirovina iz oba stupa mirovinskog osiguranja procjenjuju da će »(...) tek nakon 2035. godine osiguranici 2. stupa, zahvaljujući dugom razdoblju štednje i ako će mirovinski fondovi ostvarivati u prosjeku relativno visoke prinose, početi ostvarivati veće mirovine od mirovina ostvarenih samo u I. stupu«. Autori bez uvida u iskustva drugih tranzicijskih zemalja raspravljaju o »ispravljanju ovih nepravdi« povećanjem osnovne mirovine i povećanjem stope doprinosa u II. stupu. To i. Vukorepa (2012.: 139-140) kvalificira kao ispravljanje

\footnotetext{
${ }^{29}$ Reformom 2018. godine smanjene su ulazne naknade članovima obveznih mirovinskih fondova s $0,8 \%$ na $0,5 \%$ od uplaćenih doprinosa. Naknada za upravljanje smanjuje se tako da 2019. iznosi najviše $0,338 \%$ od ukupne imovine umanjene za financijske obveze fondova, najviše $0,3 \%$ u 2020., a za svaku daljnju godinu umanjuje se za 5,5\%, s tim da ne može biti niža od $0,27 \%$.
} 
nepravdi. Glede tranzicijskog troška i osobito dodatka na mirovine autori se zaboravljaju pozvati na plan reforme koji je postavila Svjetska banka (1998.). Marušić i Škember (2008.) na kraju ističu »(...) legitimaciju mirovinska reforma prije svega stječe svojim učincima u osiguranju socijalne sigurnosti osiguranika za rizike starosti, invalidnosti i smrti hranitelja obitelji« (361). Dakle, autori sugeriraju promjenu fokusa analize.

U vremenu krize, koja je bila katalizator promjena privatiziranih mirovina $\mathrm{u}$ ranije analiziranim tranzicijskim zemljama, ne prolazi prijedlog o kojem govori Vlada glede mirovina pod povoljnijim uvjetima - vojni osiguranici, policija i drugi, a koje se ostvaruju samo u I. stupu. Naime, za te osiguranike koji se nalaze u II. stupu njihova se ušteđevina u cijelosti htjela prebaci u I. stup. Kako je ranije kazano, Poljaci su to napravili 2003., a Hrvatska tek 2014. godine. U javnosti nisu podržani niti prijedlozi da se privremeno obustavi uplata doprinosa u II. stup dok je zemlja u krizi ${ }^{30}$.

Gospodarsku krizu identificiranu padom BDP-a, rastom nezaposlenosti, proračunskim manjkom i rastom javnog duga, u uvjetima političke nestabilnosti, ${ }^{31}$ rješava se mjerama štednje, smanjivanjem plaća u javnom sektoru, zamrzavanjem mirovina, uvođenjem kriznog poreza te kresanjem socijalnih prava. U odnosu na druge tranzicijske zemlje ironija je što se predlaže postupni porast doprinosa za drugi stup ${ }^{32}$ (Vlada RH, 2010.). Pored ostalog, u mirovinskom sustavu postupno se usklađuje zakonska dob za odlazak u prijevremenu i redovnu mirovinu; penalizira se odlazak u prijevremenu mirovinu; smanjuju se premije u III. stupu, priznaju se izdvajanja poslodavaca u III. stup kao porezno priznati trošak; predlaže se smanjenje naknada za upravljanje u II. stupu. Ukinute su olakšice za uplaćene premije osiguranja u III. stupu, kao i u životnim osiguranjima koja su uvelike istovrsna III. stupu.

Gospodarska kriza, a s time i hrvatske opcije za daljnju reformu mirovinskog sustava, zaokupile su i Svjetsku banku (World Bank, 2011.). Središnji dio Programa gospodarskog oporavka iz travnja 2010. godine bio je mirovinski sustav, a vlasti su pozvale Svjetsku banku za pripremu reforme ${ }^{33}$. Glede uvođenja dodatka na mirovine 2007. godine Svjetska banka se ne pita u kojoj mjeri je to dovelo u pitanje njihov plan pokrivanja tranzicijskog troška. Zauzima se za stav o visokim troškovima upravljanja OMF-ima i očekuje se aktivna uloga vlasti u njihovom smanjivanju. Krajnje je ironično da se u doba tako duboke krize predlaže postepeno povećavanje doprinosa za II. stup na $10 \%$ do 2016. godine. Banku ne brine tranzicijski trošak niti ulaganja OMF-a u državne obveznice, kao ni krah tržišta kapitala.

Jedan od znanstvenih izvještaja od kojeg se očekivala empirijska evidencija te identifikacija razvojnih izazova hrvatskog mirovinskog sustava s izvjesnim preporukama bio je onaj Nestića i sur. (2011.) ${ }^{34}$. U izvještaju je ključno pitanje kako i drugostupašima dati dodatak na mirovinu ne pitajući se kako je došlo do tog problema i što to znači glede ostvarivanja ciljeva reforme. Ne tematizira se ključno pitanje održivosti tranzicijskog troška, kao ni pitanje održivosti troškova upravljanja ${ }^{35}$. K tome, upitno je u hrvatskim prilikama pada BDP-a, rasta

\footnotetext{
${ }^{30}$ Prijedloge je inicirao tadašnji premijer I. Sanader.

${ }^{31}$ U srpnju 2009., sasvim neočekivano, premijer I. Sanader podnosi ostavku i na čelo vlade dolazi J. Kosor.

${ }^{32}$ Vlada je u tom smislu slijedila preporuke Svjetske banke.

${ }^{33}$ Kao član tima Svjetske banke u izradi ovog dokumenta javlja se i dr.sc. Danijel Nestić.

${ }^{34}$ Projekt je financirala Zaklada Adris što je rijetkost u hrvatskim akademskim istraživanjima.

${ }^{35} \mathrm{U}$ to vrijeme nastalo je istraživanje (Bađun i Klemenčić, 2011.) koje podastire evidenciju o prevelikim troškovima upravljanja u OMF-ima. Ovaj rad sačinjen je uglavnom temeljem analize koju je sačinila HANFA, a autor uz više upita nije mogao doći do nje.
} 
proračunskog manjka i javnog duga te rasta nezaposlenosti u ozbiljnim istraživanjima govoriti o povećanju osnovne mirovine te o povećanom izdvajanju u drugi stup. Moguće, očekivala se kvalifikacija dominantnih ulaganja OMF-a u državne obveznice s dvojbom radi li se tu o štednji ili o dugu. Premda su u drugim tranzicijskim zemljama u tom razdoblju prevladavanja financijske krize bile na dnevnom redu ove teme, $\mathrm{u}$ izvještaju se ne navodi relevantna literatura kojom bi se posvjedočili ti procesi i donesene odluke. ${ }^{36}$. Imajući u vidu ranije citirane tekstove kolega iz tranzicijskih zemalja, u ovom izvješću očekivala bi se analiza procesa hrvatske privatizacije mirovinskog sustava te dijelom učinaka koncepta predfinanciranja (eng. prefunding).

Vlada se u tom vremenu suočila s prvim umirovljenicima koji su mirovinu počeli primati iz oba stupa, a njihove su mirovine bile znatno niže od mirovina samo iz I. stupa - sustava međugeneracijske solidarnosti. Očito, radilo se o loše planiranoj reformi pa je Vlada u jesen 2011. svim dragovoljnim drugostupašima dala mogućnost povratka u prvi stup, a time su rezultati reforme »odgođeni« za narednih deset godina. Vukorepa (2012.: 140-141) ovo kvalificira kao uklanjanje »nepravde« prema osobama koje su se dobrovoljno osigurale u II. stupu. Sredstva koja su drugostupaši imali na svojim računima prenesena su u HZMO. Tada je propušteno vrednovanje učinaka štednje moguće na uzorku osiguranika kako bi se vidjelo koliko su doprinosa članovi uplatili, a koliko je s njihovih računa vraćeno u HZMO.

Članstvom u EU i mirovine postaju dijelom politike konvergencije, a politika mirovina dio je prakse metode otvorene koordinacije. »Izvještaj o starenju 2015.« kao prilog EU dokumentima trebao je ocrtati ključne hrvatske izazove te senzibilizirati ključne dionike i javnost ${ }^{37}$. Međutim, političkom voljom dio policy procesa stavljen je u funkciju promidžbe OMF-a.

Priroda poslovanja OMF-a nepoznata je javnosti, a članovi fondova koji ulažu svoja sredstva u OMF-e nisu načisto je li izvjesno da će im fond menadžeri zaraditi bolje mirovine. Kako se radi o privatnoj imovini članova, oni bi morali imati svoj glas u upravljanju $\mathrm{OMF}-\mathrm{a}^{38}$. O »vlasništvu« članova OMF-a i tome da se radi o njihovoj privatnoj imovini govori činjenica da je u 2016. godini od 59 958 novih članova svega njih 1304 samostalno odabralo obvezni mirovinski fond, što predstavlja udio od 2,2\% u ukupnom broju novih članova i neznatno smanjenje u odnosu na prethodnu godinu (HANFA, 2016.: 69).

V. Čavrak (2015.) slikovito je približio posao ulaganja u državne vrijednosnice s opravdanim pitanjem, kakva se tu ostvaruje zarada? »Pretpostavimo da smo u dugogodišnjem razdoblju uložili 100 kuna u OMF-e, a on je $70 \%$ tog novca plasirao u državne obveznice i ukamatio naš novac na 74,2 kune. To znači da imamo više novca za isplatu mirovina. No, to i nije baš tako! Nije zbog toga što je ta »zarada«

\footnotetext{
${ }^{36}$ Voditelj projekta D. Nestić istovremeno je bio konzultant Svjetske banke, pa se onda ne treba čuditi da se u projektu ne pita za kritične točke istaknute u Strategiji ili programskih tekstova N. Barra. U tom smislu, ovaj je izvještaj dio istih vrijednosnih i interesnih polazišta kao i u izvještaju Svjetske banke (World Bank, 2011.) te u dokumentu Udruženja društava za upravljanje mirovinskim fondovima (UMFO, 2011.), gdje se zaključuje: »Mirovinsku reformu treba nastaviti. Nastavak mirovinske reforme znači povećanje stope izdvajanja za drugi stup i smanjenje stope izdvajanja za prvi stup. Takva promjena stvara deficit. Međutim, taj deficit nije ništa drugo nego eksplicitno priznanje već postojeće činjenice da država neće moći ispuniti obećane mirovine današnjim zaposlenicima. Utoliko taj deficit ne treba gledati istim očima kojima se gleda deficit nastao zbog nemogućnosti financiranja tekuće potrošnje.«

${ }^{37}$ To je bila tema konferencije »Održivost mirovinskog sustava u Republici Hrvatskoj« koju su 24. veljače 2015. organizirali Ministarstvo rada i mirovinskog sustava i Hrvatska akademija znanosti i umjetnosti. Izlagači na skupu bili su D. Nestić, I. Ćipin i Z. Anušić.

${ }^{38}$ Prema reformi iz 2018. godine vlada će u nadzorne odbore mirovinskih društava imenovati jednu osobu koja će biti predstavnik članova obveznog mirovinskog fonda.
} 
od 4,2 kune ostvarena kupnjom obveznica Republike Hrvatske i u trenutku kada država iskupljuje obveznice mora platiti fondovima prinos na te obveznice od 4,2 kune. Kome pripadaju te kune? Opet tim istim poreznim obveznicima, dakle opet naš novac ili eventualno novac naše djece $\mathrm{i}$ unuka (opet generacijska solidarnost) koji ce biti porezni obveznici u trenutku kada ja budem išao u mirovinu. Kada bi to bile obveznice neke druge države, a nisu, onda bi stvari izgledale drugačije (tada bi naš prinos poticao od uvećanih poreznih uplata građana neke druge države). Dakle, kao umirovljenik imam kapitalizaciju štednje u drugom stupu, a kao porezni obveznik u istom tom iznosu imam povećani porezni trošak jer moja država mora iskupiti (moje) obveznice da plati prinos fondovima kojeg fond menadžeri meni prikazuju kao moju zaradu. Dakle, pozitivni saldo kapitalizacije platio sam svojim novcem, plaćanjem većeg poreza, a saldo moje financijske imovine zbog toga je ostao isti. Ni to nije sve jer se u međuvremenu iz moje uplate u drugi stup moraju platiti troškovi upravljanja pa sam za taj iznos u gubitku« (2015.: 7).

Samodol (2014.) ovako kvalificira ovu činjenicu: »(...) stalnu negativnu razliku između prinosa mirovinskih fondova i kamata na izdane državne obveznice i obrnuto plaćaju jedne te iste osobe. Jednom u funkciji poreznog obveznika, a drugi put u funkciji člana mirovinskog fonda.« Adascalitei i Domonkos (2018.: 50) ovo nazivaju problemom dvostrukog plaćanja gdje sadašnji porezni obveznici moraju financirati sadašnje umirovljenike i štedjeti za vlastitu mirovinu.

Drugi dio zarada očekuje se u dioničkom portfelju, međutim, nema javnih podataka o dioničkom portfelju OMF-a, pa Čavrak analizira poznati primjer ulaganja u dionice Petrokemije iz Kutine. »U drugoj polovini 2013. godine nekoliko OMF-a uložilo je novac u 605717 dionica radi dokapitalizacije Petrokemije po nominalnoj cijeni 170 kuna po dionici, što znaci da je uloženo 102971 973 kuna našeg novca. U međuvremenu OMF-i su kupili na sekundarnom tržištu još 493529 dionica te tvrtke. Na dan 22. 1. 2016. godine burzovna cijena tih dionica iznosila je samo 12,92 kune. Cijena tih dionica u dvije godine pala je za čak $92,4 \%$. Ako bi sada trebalo prodati navedene dionice da se započne isplata mirovina iz drugog stupa, to bi značilo da bi OMF-ovi izgubili 95146 103 kuna. Tom gubitku treba pridodati i nepoznati gubitak vrijednosti dionica kupljenih na sekundarnom tržištu« (2015.: 8).

Ulaganja u ovakve projekte dokapitalizacije događa se po političkim nalozima. OMF-i pomažu nereformskim vladama, a vlade ne dovode u pitanje poslovanje OMF-a i rezultate privatizacije mirovinskog sustava ${ }^{39}$.

Čavrak upozorava kako za isplatu budućih mirovina nisu samo važni današnji nominalni prinosi, nego je važnije i očuvanje supstance kojom OMF-ovi raspolažu. Ako se dogodi pretežiti pad vrijednosti dionica u njihovom portfelju, kao u slučaju Petrokemije, sasvim je izvjesno da neće biti dovoljno novca za isplatu mirovina. U nezaštićenoj osnovnoj supstanci Čavrak vidi najveći dugoročni rizik, a budući umirovljenici nisu upozoreni i objektivno nemaju pravog uvida niti mogućnost kontrole novca čiji su »vlasnici«. Cavrak se zalaže za javnu objavu stanja i strukture portfelja $\mathrm{OMF}-o v a^{40}$. U kontekstu iznesenog bilo bi

\footnotetext{
${ }^{39}$ Zakonom o obveznim mirovinskim fondovima (2014.) uvode se mirovinski fondovi kategorije A, B, i C, a imaju različite strategije ulaganja, najveći je rizik u mirovinskom fondu kategorije $\mathrm{A}$, a najmanji u kategoriji C.

${ }^{40}$ Tek od 2015. uvedena je obveza OMF-ima o podnošenju skupnog izvješća Saboru o radu (A-Z Obvezni mirovinski fond i dr. (2017.) »Izvještaj o radu obveznih mirovinskih fondova za 2016. godinu «) iz kojeg se mogu pročitati tek elementarni podaci i njihovi hvalospjevi o prinosima, a ranije su to fondovi radili pojedinačno. Neobično je da mirovinska osiguravajuća društva, kao privatne tvrtke, podnose izvješće Saboru. Taj bi posao trebalo povjeriti HANFI i trebao bi biti znatno sadržajniji kako bi se vidjeli svi detalji relevantni za poslovanje.
} 
prevažno istražiti koliko su OMF-i izgubili supstance 2008. godine prilikom kraha tržišta kapitala? OMF ulaganjem u dionice tvrtki čija je vrijednost padala na burzi, da bi spasili plasmane banaka vlasnica također se gubila supstanca za buduće mirovine. Mediji navode slučajeve Nexe grupe, Inge, Quaestusa i Metroneta (Globus, 2014.).

Članstvo Hrvatske u Europskoj uniji i institut europskog semestra ponovno su na dnevni red javnih rasprava vratili temu II. stupa. Naime, u Nacionalnom programu reformi 2015. očekuje se kontinuirano smanjenje javnih rashoda za mirovine, a to se argumentira i činjenicom: »Od 2027. nadalje većina novih umirovljenika primat će osnovnu mirovinu iz I. stupa i mirovinu iz II. stupa. To znači da će se rashodi za mirovine isplaćene iz $\mathbf{I}$. stupa postepeno smanjivati. To smanjenje će biti utoliko značajnije iz razloga što umirovljenici koji će primati mirovinu iz oba stupa neće imati dodatak od $27 \%$ na mirovinu koja se isplaćuje iz I. stupa.« (Vlada RH, 2015.: 17).

Tim više, sredinom 2017. ušli su prvi obvezni drugostupaši u mirovinu, a njihove su mirovine znatno niže od onih koji dobiju mirovinu samo iz I. stupa. Društva za upravljanje OMF-ima mobilizirala su svoje stručnjake te vrše pritisak u javnosti kako bi se, po njima, ispravile ove nepravde ${ }^{41}$.

Provedba reforme, posebno $\mathrm{u}$ okolnostima gospodarskog šoka, nije monito- rirana niti evaluirana, a neupitno vodstvo Svjetske banke, neosjetljivo na očite promašaje, pod svaku cijenu spašava reformu. $\mathrm{K}$ tome, kritički akademski uvidi o učincima reforme bivaju zasjenjeni onima koji se pokrivaju narativom Svjetske banke.

\section{ANALIZA JAVNOG DISKURSA O PRIVATIZACIJI MIROVINSKOG SUSTAVA}

Javni diskurs o pitanjima socijalne politike važan je instrument njihove legitimizacije te postizanja izvjesnih učinaka glede oblikovanja javnog mišljenja. Analiza javnog diskursa u našim istraživanjima o socijalnoj politici ponešto se prakticira tek u novije vrijeme (Baturina, 2017.). U poljskom primjeru reforme II. stupa vidjelo se kako su rasprave u medijima imale važnu ulogu u oblikovanju javnog mnijenja te pod tim pritiskom donošenja važnih odluka. U poljskom iskustvu otvorenost medija, sudjelovanje kompetentnih stručnjaka i predstavnika relevantnih dionika pomogli su izgradnji stavova građana o ovoj temi. Dodatni su pritisci ostvarivani i iznošenjem prijetećih poruka u utjecajnom globalnom mediju ${ }^{42}$.

Ovdje se analiziraju tri tipa javnog diskursa: prvi, pokrenut na sučelju časopisa Banka $^{43}$ gdje su objavljeni autorski tekstovi stručnjaka, drugi, kroz intervjue i izvješća koji su očito dio marketinške strategije OMF-a te treći, povezani s nastojanjima

${ }^{41} \mathrm{OMF}$, bolje reći obvezna mirovinska društva - OMD, financirali su izvjesnu demografsku studiju te organizirali konferenciju u veljači 2017. na kojoj su bili i predstavnici vlade, da bi se naslovile rečene »nepravde» $\mathrm{i}$ obećalo povećanje doprinosa u II. stup za $1 \%$ i smanjenje izdvajanja u I. stup za 1\%. Vidjeti: Jutarnji list, 1. 3. 2017. »Vlada uvodi dječji dohodak «, gdje se ističe stav fond menadžera o kuni uloženoj u drugi stup koji isplaćuje 2,4 kune te potom stav stručnjaka V. Šonje da izdvajanja u II. stup treba povećati na $8 \%$.

${ }^{42}$ Ovo se odnosi na tekstove u poznatom Financial Time.

${ }^{43}$ Radi se o raspravi koju je autor teksta, Bežovan (2014. i 2014.a) pokrenuo na sučelju www.banka.hr u siječnju 2014. godine kao reakciju na tekst Katarine Ott »S drugim stupom oprezno!« K. Ott je bila članica stručne skupine ranije spomenutog Povjerenstva za mirovinsku reformu. U raspravi su sudjelovali: Željko Potočnjak (2014.), Damir Grbavac (2014.), Predrag Bejaković (2014.), Hrvoje Simović (2014.) i Velimir Šonje (2014. i 2014.a). Izdavač je ovu domenu ugasio, međutim, dostupna je preko Nacionalne i sveučilišne biblioteke u Zagrebu. Potočnjak je u Povjerenstvu za mirovinsku reformu bio član Savjeta povjerenstva te voditelj stručne skupine za izradu nacrta popratnih mirovinskih zakona (NN, 27/1998.). On je i ranije upozorio (Potočnjak, 2000.) da se u određivanju ciljeva promjena mirovinskog sustava nisu posebno iskazale ni struka, ni znanost. 
OMF-a da se obveznim drugostupašima dade dodatak na mirovinu od $27 \%$.

\section{Rasprava na sučelju www.banka.hr}

Poticaj za raspravu bio je tekst K. Ott (2014.) u kojem govori kako je Sanader, pokušavajući spasiti proračun, 2009. najavio ukidanje drugog stupa, nazvavši ga čak i promašajem, te nastavlja: »Pet godina kasnije, opet početkom godine i opet u raspravama o spašavanju proračuna, javljaju se iste ideje. Ministar financija zasad tvrdi kako je zadiranje u mirovinske fondove posljednja opcija koju bi Vlada koristila za smanjenje proračunskog deficita, ali istovremeno plasira - za sigurnost mirovinskog sustava podjednako opasnu - ideju o većem investiranju mirovinskih fondova u trgovačka društva poput HEP-a, Janafa ili autocesta.« Autorica navodi zabrinjavajući primjer nacionalizacije mirovinskih fondova u Mađarskoj te smanjenje izdvajanja u II. stup u Poljskoj, s naglaskom da ona nije ukinula II. stup. Međutim, ne navodi se Slovačka koja je 2008. ukinula obvezno članstvo u II. stupu, a Poljska je krajem 2013. učinila II. stup dragovoljnim (Naczyk i Domonkos, 2016.). Ott zagovara povećanje izdvajanja u II. stup.

Što se može zaključiti o ovoj raspravi? ${ }^{44}$ Veći dio sudionika ne prati reforme mirovinskog sustava u tranzicijskim zemljama. Rasprava se teško usmjerava prema činjenicama, kao što je održivost tranzicijskog troška, a teško se prepoznaju i drugi rizici u sustavu, kao što su: visoke naknade i provizije društava za upravljanje OMF-ima, promašena ulaganja u dioničkom portfelju te prevelika ulaganja u državne obveznice.
U obrani II. stupa dominantno se koriste narativi Svjetske banke koji su prevrednovani u Slovačkoj, Mađarskoj i Poljskoj gdje je bila ukinuta obveznost II. stupa.

\section{Intervjui kao dio marketinške strategije društava za upravljanje OMF-ima}

Početak velike mirovinske reforme bio je obilježen intenzivnom marketinškom kampanjom kako bi se građane uvjerilo u koristi uvođenja II. stupa kao uloga u veće mirovine koje će dobivati. Novine su bile preplavljene letcima s izračunima većih mirovina iz I. i II. stupa, a za razliku od mirovina samo iz I. stupa. Kampanja je poticala i premiranu štednju u III. stupu.

$\mathrm{S}$ gospodarskom krizom i krizom javnih financija te nakanama za privremeno ukidanje uplata u II. stup ili njegovog potpunog ukidanja jača i marketinška kampanja društava za upravljanje OMF-ima. Kao dio te kampanje analiziraju se dva opsežna intervjua J. Piñera, čileanskog reformatora mirovinskog sustava. ${ }^{45}$ Piñera u prvom intervjuu ističe kako je državu odvojio od mirovinskog sustava i omogućio ljudima da sami štede za mirovine. Ljudi su dobili kontrolu nad svojim životima. Ta je reforma utjecala na smanjenje siromaštva sa $45 \%$ na $15 \%$. Ističe kako reforma savršeno funkcionira već 32 godine i uvjeren je da bi tako moglo biti i u Hrvatskoj, ali o tome, prema njemu, odlučuju hrvatski političari. Zaključuje se da svijetom kruži bauk bankrotiranog državnog mirovinskog sustava.

Dvije godine poslije Piñera govori da je mirovina prosječnog Čileanca 800 dolara,

\footnotetext{
${ }^{44}$ Rasprava je bila pobudila izvjestan interes javnosti, ali ju je naprasno prekinula urednica sučelja koje je bilo u vlasništvu Hrvatskog udruženja banaka.

${ }^{45}$ Čileanski reformator: »Odvojio sam državu od mirovinskog sustava«, Večernji list 13. 6.2012., »Zgranulo me što mirovinci 72,3\% imovine drže u obveznicama RH, dakle, u 'smeću' «, Večernji list 30. 8. 2014. Piñera je dolazio u Hrvatsku kao predavač na ljetnoj školi o temi »Temelji liberalne demokracije«, koju je organizirao Centar za obnovu kulture. Njegov dolazak sponzorirala su dva društva za upravljanje OMF-ima. Piñera je 2014. godine prilikom boravka u Hrvatskoj govorio i na Hrvatskoj televiziji o uspjesima mirovinske reforme u Čileu i superiornosti privatizacije nad javnim sustavom mirovina.
} 
samo 200 dolara niža od prosječne plaće. Njegova je mirovinska reforma do tada preživjela šest vlada. Međutim, ostao je zgranut činjenicom da su hrvatski fondovi 72,3\% imovine uložili u državne obveznice koje su dvije razine u rejtingu investicijskog smeća. Zanimljivo je kako Piñera ističe da mu je eliminacija siromaštva životna misija. Ipak, nije spomenuto da je čileanski mirovinski sustav u to doba već bio zapao u krizu, pa je 2008. provedena prva reforma (Barr i Diamond, 2016.) kako bi se pomoglo onima koji su uslijed kraćeg i isprekidanog staža primali male mirovine. $\mathrm{K}$ tome, ishodi privatizacije glede zamjenske stope nisu niti blizu $80 \%$ kako se navodi u intervjuu.

\section{Medijska kampanja OMF-a da se obveznim drugostupašima da dodatak na mirovinu}

Pitanje održivosti II. stupa, imajući u vidu provedene reforme u zemljama višegradske skupine te rast javnog duga, postaje sve relevantnije pitanje u javnim raspravama. Mediji, osobito dnevne novine, posebno se pozivaju na peticiju protiv zamrzavanja uplata u II. stup ${ }^{46}$ te u svojim tekstovima protežiraju stručnjake koji su potpisali peticiju.

Ovdje se analiziraju pisanja dvije najveće dnevne novine o II. stupu u vremenu od listopada 2016. do kraja 2017. godine. ${ }^{47}$ Analizom se hoće pokazati kako je praće- nje prevažne teme II. mirovinskog stupa zapravo medijska kampanja koju se provodi za interese OMF-a. ${ }^{48} \mathrm{U}$ tom vremenu evidentirano je 69 tekstova različitih formata i obima koji se bave ovom temom, a od toga su 42 u Večernjem listu.

Po formatu 23 teksta su autorski tekstovi u kojima se dijelom poziva i na mišljenja stručnjaka. Zatim, 17 su izvješća sa skupova, 13 razgovori s više sugovornika, a pet su razgovori s jednim sugovornikom. Ostalih 11 tekstova pripada kategoriji izjava ili usputnih komentara o temi. Ovdje se ne analiziraju brojni plaćeni tekstovi Udruge društava za upravljanje mirovinskim fondovima i mirovinskih osiguravajućih društava naročito učestali poslije krize u Agrokoru gdje su bili izloženi OMF-ima ${ }^{49}$.

Iz kruga stručnjaka i političara novinarima su glavni sugovornici oni koji neupitno zagovaraju II. stup. Najčešći sugovornik je D. Nestić čije su izjave popraćene i osam puta s fotografijom, a od toga šest puta u tekstovima Lj. Gatarić. Zatim su tu političari - M. Mrsić s dvije izjave s fotografijama i S. Hrelja s tri izjave popraćene fotografijama. Ostali stručnjaci zagovornici II. stupa po učestalosti javljanja su: I. Vukorepa, Z. Anušić, P. Bejaković i B. Cota. Znatno se rjeđe, bolje reći sasvim zanemarivo, mogu pročitati izjave ili stavovi stručnjaka osporavatelja i zago-

${ }^{46}$ Peticiju su protiv prijedloga Ivana Lovrinovića, saborskog zastupnika, za zamrzavanje uplata u II. stup kako bi se smanjio proračunski deficit početkom 2016. potpisali: Martina Dalić, Sandra Švaljek, Maja Vehovec, Željko Potočnjak, Vuk Vuković, Predrag Bejaković, Andrea Mervar, Nevenka Čučkovic, Maruška Vizek, Marina Kesner Škreb, Velimir Šonje i Ivana Vukorepa.

${ }^{47}$ Dakle, to su Večernji list i Jutarnji list. O okruglom stolu »Hrvatski mirovinski sustav i održivost drugog stupa«, održanom 21. listopada 2016. u Zagrebu, u organizaciji Revije za socijalnu politiku, napisan je tekst u Večernjem listu i bio je posvećan samo izlaganju D. Nestića, a ostali su izlagači i neki njihovi stavovi tek spomenuti. Znakovito, Jutarnji list koji prati ovu temu nije ništa javio o skupu. Autor ovog teksta prosvjedovao je e-porukom novinarki Lj. Gatarić koja je napisala spomenuti članak pod naslovom. Od tog vremena do danas autor je u prepisci s novinarima: Lj. Gatarić, G. Drača, A. Milovan, V. Vresnikom, F. Laušić, koji pišu o mirovinama. U novije vrijeme uključio je i D. Nestića te P. Bejakovića koje spomenuti novinari najčešće intervjuiraju. Znakovito, Jutarnji list nije pisao niti o okruglom stolu koji je u Hrvatskom saboru organizirao Most nezavisnih lista 9. ožujka 2016.

${ }^{48}$ Analizirani tekstovi dobiveni su presscut tehnikom na spomen pojma »drugi mirovinski stup «.

${ }^{49}$ Primjer takvog teksta Večernji list, 2. 11. 2017. »Novac članova u II. stupu predmet je nasljeđivanja«. 
vornika rasprave o II. stupu: Lj. Jurčića, D. Jakovljevića, I. Lovrinovića, V. Čavraka, G. Santinija i G. Bežovana, kao i sindikalista J. A. Petrović i A. Pezelj.

Novinska forma intervjua ima veću težinu, daje više prostora $\mathrm{i}$ značaja temi. Od pet intervjua dva imaju stručnjaci: P. Bejaković $^{50}$ i D. Nestićs ${ }^{51}$, te fond menadžeri P. Vlajićc ${ }^{52}$ i D. Grbavac ${ }^{53}$ te Z. Anušićc ${ }^{54}$ stručnjak Svjetske banke - prikaz njegovog izlaganja na skupu. U intervjuima se ne postavljaju »nepredviđena« pitanja, a po sadržaju i stavovima trebaju poslužiti kako bi se javnost uvjerilo u ispravnost reforme, nužnost davanja doplatka na mirovinu od $27 \%$ i drugostupašima. Hvali se profitabilnost OMF-a te se poriču sumnje o gubitcima glede izloženosti OMF-a Agrokoru ${ }^{55}$.

Glavna novinarska pera koja prate ovu temu su Lj. Gatarić, Večernji list, G. Drljača i A. Milovan, Jutarnji list. Drljača piše autorske, uredničke tekstove, i te su poruke vidljive u tekstovima A. Milovana. Gatarić ima uglavnom iste sugovornike koji su zagovornici II. stupa. Drljača čestita Lj. Gatarić koja, »(...) uporno iznova pokreće vrlo važno pitanje o opasnosti ukidanja 27 posto redovnog dodatka na mirovine svih onih koji su štedjeli u 2. stupu, (...)« te prijeti Vladi koja takav dodatak od $27 \%$ ne vrati da mora otići s vlasti ${ }^{56}$. Ukidanje dodatka je za Drljaču neprihvatljivo iz četiri razloga, a prvi je, što je taj dodatak uveden kao svojevrsno priznanje da je prvi stup međugeneracijske solidarnosti propao. Vladu optužuje da u njoj sjede osvjedočeni mrzitelji individualne štednje u II. stupu te prijeti podnošenjem ustavne tužbe i organizacijom referenduma.

Lj. Gatarić pita ${ }^{57}$ se čemu mirovinska reforma ako Vlada ne želi rješenje koje bi dovelo do rasta mirovina iz II. stupa. U tom smislu polemizira sa stavovima ministra $\mathrm{M}$. Pavića koji kaže da Vlada neće žuriti s prijedlogom rješenja jer tek 2019. očekujemo veći priljev novih umirovljenika iz II. stupa. Ministar kaže: »Moramo analizirati utjecaj dodatka da se ne bi dogodilo da umirovljenici iz II. stupa uz dodatak dobiju veće mirovine od onih iz I. mirovinskog stupa.« Gatarić konstatira kako je Vlada slično obrazložila odbijanje SDP-ova prijedloga da se po hitnom postupku isplati dodatak od $27 \%$ za II. stup. Ministru su suprotstavljeni stavovi I. Vukorepe i D. Nestića, zagovornika II. stupa i isplate dodatka od $27 \% \%^{58}$. Ova novinska stranica dopunjena je i stavom slovačkog šefa mirovinskih fondova, koji prezentira novinarka M. Šunjega ${ }^{59}$, o potrebi ustavne zaštite II. stupa, s iskustvom zemlje gdje je ukinuta obveznost II. stupa, smanjen

\footnotetext{
${ }^{50}$ Večernji list, 21. 9. 2017. »Ne treba se vraćati unatrag i ukidati drugi stup, on nije izvor problema«, intervju na cijeloj stranici.

${ }_{51}^{51}$ Večernji list, 27. 9. 2017. »Padnu li mirovine, reforma nema smisla«, intervju na dvije petine stranice.

${ }^{52}$ Večernji list, 25. 8. 2017. »U postojećim okolnostima nova ulaganja u Inu ne razmatramo«, intervju na dvije stranice.

${ }^{53}$ Večernji list, 25. 8. 2017. »U postojećim okolnostima nova ulaganja u Inu ne razmatramo«, intervju na dvije stranice.

${ }_{54}^{5}$ Jutarnji list, 21. 10. 2017. »Udruge umirovljenika iz zablude napadaju drugi mirovinski stup«, intervju na trećini stranice.

${ }^{55}$ Na upit saborskog zastupnika Ivana Lovrinovića HANFA (2018.) je Odboru za financije i državni proračun Hrvatskog sabora dostavila odgovor u kojem se navodi da su OMF-i do rujna 2018. godine na dionicama Agrokora izgubili 801 milijun kuna, odnosno $0,81 \%$ neto vrijednosti imovine. Tek bi trebalo izračunati stvarni gubitak ostvaren gubitkom ove supstance.

${ }^{56}$ Jutarnji list, 21. 9. 2017. Gojko Drljača, »Vlada koja takne 27\% dodatka na mirovine mora otići s vlasti «, tekst na cijeloj stranici.

${ }^{57}$ Večernji list, 21.10. 2017. »Paviću manje mirovine nisu diskriminacija, veće bi bile!?«, cijela stranica teksta.

${ }^{58} \mathrm{U}$ tekstu su izdvojeni stavovi ovih stručnjaka s njihovim fotografijama, podnaslovljeni »Drugi stup - Instrument sigurnosti $\ll$.

${ }^{59}$ Večernji list, 21. 10. 2017. »Kopecki: Drugi stup treba zaštititi Ustavom«.
} 
je doprinos, a u zaštiti toga nije im pomogao pravorijek tamošnjeg ustavnog suda.

Ovaj pritisak na ministra Pavića dio je orkestrirane kampanje koju u autorskom tekstu nešto ranije iznosi Drljača, ${ }^{60} \mathrm{~s}$ podnaslovom »Ministar Pavić prvi put poručio da su spremni zadržati 'dodatak 27 posto'«. Drljača ima svoje objašnjenje dodatka od $27 \%$ koji je uveden »(...) jer je prvi mirovinski stup međugeneracijske solidarnosti bankrotirao te više po starim formulama nije mogao osiguravati mirovine dostatne za egzistencijalni minimum velikom broju umirovljenika.«

Za pristup Lj. Gatarić zanimljiv je tekst $^{61}$, koji je poslije uredničke intervencije, kao sugovornike uključio i kritičare drugog stupa A. Pezelj i G. Bežovana. Ostali sugovornici, sa znatno opsežnijim komentarima od prethodnih dvoje, su D. Nestić, Z. Anušić i I. Vukorepa te tadašnji ministar T. Ćorić. Gatarić brani gubitke OMF-a u Agrokoru jer »(...) minusi se još stignu popeglati kad isplate krenu (...)«, a ne govori o gubitku imovine. Anušić zaziva Ustavni sud. Međutim, »navijačkim « uredničkim komentarom novinarka zaključuje kako se sa stavovima Bežovana ne slaže I. Vukorepa! Važno je istaknuti, to je prvi tekst novinarke Gatarić, a nema sličnih u obadvije analizirane novine, kojim se barem donekle predstavljaju različita mišljenja o II. stupu.

U ovom razdoblju samo tekst $\mathrm{R}$. Boškovića $^{62}$, kojim prenosi rezultate istraživanja
V. Čavraka (2016.), iznosi kritičku analizu II. stupa. Ističe se kako je četvrtina javnog duga nastala kao posljedica stvaranja II. stupa i da to doprinosi da nam je kreditni rejting u razredu »smeća«. Ističe se i problem proračunskog manjka koji generira II. stup te neodrživosti tranzicijskog troška.

Zabilježena je i rasprava u kojoj je D. Novoselec $^{63}$, donedavni čelnik najvećeg OMF-a, reagirao na autorski tekst G. Bežovana. ${ }^{64}$ Novoselec hvali Nestića, Bejakovića i Vukorepu kao stručnjake koji zagovaraju II. stup. Međutim, poslije Bežovanovog65 odgovora rasprava se nije nastavila. Očito, i hrvatska akademska zajednica ne čini se odgovornom kako bi sudjelovala u raspravi o javnoj temi koja je bila predmetom potpisivanja »akademske peticije $^{66}$.

Izloženi uvidi o pisanju novina upućuju na zaključak da ne postoji argumentirani javni diskurs o ovoj temi. Dominanto iznošenje mišljenja zagovornika II. stupa, kao i predstavnika mirovinske financijske industrije, bez postavljanja pitanja o praksama u drugim zemljama, problemima tranzicijskog troška kao ni o naknadama i provizijama koje se zaračunavaju govori o nedovoljnoj objektivnosti novinara i stavljanje novina u funkciju medijske kampanje za račun OMF-a ${ }^{67}$.

Ipak, napori zagovornika da svi dobiju dodatak od $27 \%$ urodili su polovičnim plodom. U postupku ostvarivanja prava osiguranici prvog i drugog stupa, dobro-

\footnotetext{
${ }^{60}$ Jutarnji list, 2. 10. 2017. »Još rade izračune kako skresati sve buduće mirovine«

${ }^{61}$ Večernji list, 10. 6. 2017. »Ništa od sigurne starosti, mirovine bi se mogle uskoro pretvoriti u socijalnu pomoć«. Prije toga autor ovog teksta prosvjedovao je uredniku Večernjeg lista zbog pristranog pisanja Lj. Gatarić i pristranog odabira sugovornika.

${ }^{62}$ Večernji list, 3. 11. 2016. »Zbog 2. stupa daleko smo od eurozone i u rejtingu 'smeća' «.

${ }^{63}$ Večernji list, 16. 11. 2017., »'Hejterski' o 2. stupu, opasno kockanje s akademskim ugledom«.

${ }^{64}$ Večernji list, 11. 11. 2017., »Drugi je mirovinski stup opasno kockanje, svi su pobjegli osim Hrvatske«, tek je objavljen u cijelosti poslije dugog i temeljitog autorovog lobiranja.

${ }^{65}$ Večernji list, 22. 11. 2017. »Upravlja li zemljom Vlada ili mirovinski fondovi?«.

${ }^{66}$ Znakovito je upozoriti na stav Ž. Lovrinčevića u intervjuu, Večernji list, 5. 1. 2018. »Ekonomski smo neuspješni i zato ne ide bez pokroviteljstva SAD-a ili Rusije.«, »Naš drugi stup je čudan mutant koji druge zemlje napuštaju. Govorim o radikalnoj promjeni da se drugi stup ugasi i pretvori u treći stup.«

${ }^{67}$ Ivana Vukorepa (2018.), u izvješću za Europsku komisiju, kao ekspert European Social Policy Network, navodi kako se vodi vruća rasprava između osporavatelja i zagovornika ukidanja II. stupa koju redovito prate televizija i dnevne novine. Vukorepa je potpisnica peticije protiv ukidanja II. stupa.
} 
voljni i obvezni, moći će birati u kojem će sustavu ostvariti mirovinu:

- mirovinu samo u prvom stupu s dodatkom od $27 \%$ uz prijenos sredstava iz obveznog mirovinskog fonda u državni proračun

- ako izaberu ostanak u drugom stupu, na mirovinu iz prvog stupa pripada im dodatak od $27 \%$ za staž ostvaren do kraja 2001. godine, a na dio mirovine koja im pripada za mirovinski staž ostvaren nakon uvođenja drugog stupa, to jest, od 2002. godine, određuje se dodatak od $20,25 \%$.

Osnovnu mirovinu s navedenim dodatkom od 27\% i 20,25\% isplaćuje Hrvatski zavod za mirovinsko osiguranje, a uz to korisnici drugog stupa ostvaruju i mirovinu koju isplaćuje mirovinsko osiguravajuće društvo.

\section{EVALUACIJA KONCEPTA, PROCESA I DIJELOM UČINAKA PRIVATIZACIJE}

Temeljem ranije provedene analize procesa privatizacije hrvatskog mirovinskog sustava te analize ishoda reformi u tranzicijskim zemljama iznose se nalazi evaluacije glede koncepta, procesa i dijelom učinaka II. mirovinskog stupa. Kao kriterije evaluacije koriste se načela: vrijednosno određenje glede koncepta, pretpostavke za pokretanje reformi, institucionalni kapaciteti za provedu, neizvjesnosti u gospodarstvu, rizici ulaganja na tržištu dionica, rizik ulaganja u države obveznice, rizik velikih troškova upravljanja te rizik održivosti tranzicijskog troška.

Evaluacija procesa privatizacije hrvatskog mirovinskog sustava, kao kriterij, podrazumijeva načelnu, vrijednosno utemeljenu, analizu i raspravu. Naime, imajući u vidu poslanje javnog mirovinskog sustava kao osiguranja za rizike starosti, invalidnosti i smrti hranitelja obitelji te problem održivosti istoga postavlja se pitanje, kako ga učiniti održivim? Barrova argumentacija (2002.) da se to čini kombinacijom smanjivanja naknada i povećanja doprinosa, a ne privatizacijom čini se uvjerljivom.

Kapaciteti za provođenje reforme trebaju se vrednovati kao kriterij, odnosno pretpostavke za pokretanje reformi i kao doprinosi izvjesnim učincima. Reformu je priredila Svjetska banka, a organizacijski i institucionalni kapaciteti države kako bi se provodio monitoring i evaluacija učinka tog procesa nisu bili izgrađeni ${ }^{68}$. Stoviše, monitoring i evaluacija reforme - privatizacije kičme sustava socijalne sigurnosti, nisu bili predviđeni. Pored toga, nisu postojali stručni i znanstveni kapaciteti koji bi pratili što se događa s reformama u drugim zemljama kako bi se moglo učiti iz iskustva drugih. Očito je, reforma je u vlasništvu Svjetske banke i OMD-a koji manipuliraju rezultatima, a ne države i osiguranika. Treba se složiti s K. Müller (2002.) da je u takvim okolnostima privatizacija mirovinskog sustava postala vrlo opasna strategija.

Razvijeno tržište kapitala trebalo je biti naredna važna pretpostavka privatizacije mirovinskog sustava. Tržište kapitala u vrijeme početka reforme bilo je još u povojima, a s krizom 2008. došlo do njegovog sloma (Rohatinski, 2015.; Bošković, 2017. $)^{69}$. Ulaganja OMF-a bila su dio igre napuhivanja burzovnog balona. Tržište kapitala nije se oporavilo ni do 2018. godine, kao ni poslije, kada se u izvješću OMF-a govori da se zbog izrazito nelikvidnog domaćeg tržišta dionica ulaže u državne obveznice. Dakle, obećavani ubrzani gospo-

${ }^{68}$ Skromne institucionalne kapacitete u Hrvatskoj u odnosu na tranzicijske zemlje identificiralo je i komparativno istraživanje Bohle i Greskovits (2012.).

${ }^{69}$ Crobex je s najviše vrijednosti od 5 392,24 bodova sredinom listopada 2017. pao 71,3\% u 2018. godini na razinu s kraja 2004. godine (Bošković, 2017.). Pad vrijednosti financijske imovine, ispuhivanje na tržištu dionica i vrijednosnih papira, iznosio je 2008. oko 47 milijardi kuna (Rohatinski, 2016.: 120). 
darski rast i nova zapošljavanja, kao učinci reforme, nisu se ostvarili.

Povratak toliko velikog broja dragovoljnih drugostupaša u I. stup nije bio predviđen i promašaj je reforme. Naime, mirovine iz I. i II. stupa trebale su biti veće od onih iz I. stupa. U tom smislu, trebalo bi na odgovarajućem uzorku provjeriti, koliko su oni uplatili u II. stup i koliko se na ime tih uplata i ostvarenih zarada vraća u I. stup. To bi bio doprinos analizi učinaka. Nadalje, temeljem takve analize, odgovorna bi vlast donijela odluku o povratku svih dragovoljnih drugostupaša u I. stup, s tim da dio članova s boljim dohodcima može preuzeti rizik i ostati u II. stupu.

Kao dio evaluacije treba prevrednovati uplate doprinosa na račune beneficiranih osiguranika te napraviti računicu koliko se od toga, zajedno sa zaradama, vratilo u I. stup. K tome, važno je upozoriti da se u ovom slučaju nije učilo, primjerice, iz poljskog iskustva ${ }^{70}$ te se o ovoj činjenici može govoriti kao o promašaju reforme.

Dakle, povratak ove dvije kategorije drugostupaša u I. stup govori o nedostatnim institucionalnim kapacitetima za pripremu i praćenje ključne nacionalne reforme koja je u rukama Svjetske banke i stranih banaka ${ }^{71}$.

Makroekonomski šok, kao načelo neizvjesnosti, ilustriran višegodišnjim padom BDP-a, rastom javnoga duga te gubitkom velikog broja radnih mjesta, Vlada je 2010. liječila povećanjem stope PDV-a s $22 \%$ na $25 \%$, kriznim porezom na plaće, mirovine i ostale primitke veće od tri tisuće kuna, smanjivanjem po- vlaštenih mirovina te, za razliku od drugih tranzicijskih zemalja, najavila postupni porast doprinosa za II. stup. Ovaj šok utjecao je i na demografski šok (Barr govori o šokovima) - seljenje stanovništva iz zemlje, kao novu neizvjesnost pred gospodarstvo i održivost mirovinskog sustava. Makroekonomski šok imao je negativne učinke ne reformu.

Glede rizika ulaganja na tržištu dionica ne raspolaže se s dovoljno javno dostupnih podataka za analizu dioničkog portfelja OMF-a, a važan je dio evaluacijskog procesa, evaluacije učinka, s naglaskom na tri činjenice. Treba istražiti neke u javnosti istaknute slučajeve gdje su OMF-i kupovali dionice tvrtki kako bi spasili plasmane svojih vlasnica banaka ${ }^{72}$. S druge strane, ulaganja OMF-a po nalogu Vlade u dokapitalizacije i spašavanje »važnih « tvrtki otkrit će rizike »političke« redistribucije »privatnog $«$ kapitala. Analizirani slučajevi bit će pouzdani indikatori gubitka supstance kapitala. Evidencija o nominalnom gubitku supstance u slučaju ulaganja u Agrokor poticaj je za analizu stvarnih gubitaka. Treća činjenica odnosi se na dvojbe glede nominalne cijene dionica u portfelju, naspram tržišne vrijednosti, a temeljem koje se zaračunavaju naknade za upravljanje kao prihod OMF-a.

Rizik ulaganja u državne obveznice pokazao se kao slijepa ulica reforme i značio je povećanje javnog duga. Na djelu je klasični koncept financijalizacije, preusmjeravanje ušteđevine u vrijednosne papire, država sama sebi uz posredništvo i proviziju

\footnotetext{
${ }^{70}$ Veoma brojna braniteljska populacija ima povlaštene mirovine i trebalo bi imati odgovore na pitanja, što ako osnovna mirovina i mirovina iz II. stupa budu manje od zajamčene im mirovine. Osobito valja imati na umu povećanje ovih prava uvedeno 2017. godine Zakonom o hrvatskim braniteljima iz Domovinskog rata i članovima njihovih obitelji (NN, 121/2017.). Mirovinskom reformom 2018. godine zaključeno je da će osiguranici u II. stupu koji ostvaruju mirovinu po posebnim propisima (branitelji), kao i korisnici najniže mirovine, mirovinu ostvarivati samo u prvom stupu, a njihova sredstva iz drugog stupa bit će prenesena u državni proračun. Onda, nije jasna logika zašto su oni uopće osiguranici u II. stupu.

${ }^{71}$ U 2016. s 4973 računa u II. stupu sredstva su prenesena u I. stup - Hrvatski zavod za mirovinsko osiguranje, a 61 član je prenio sredstva u mirovinsko osiguravajuće društvo radi isplate mirovina iz II. stupa (HANFA, 2016.: 69). Krajem iste godine u II. stupu mirovinu je primalo samo 189 osiguranika. Mediji su zabilježili da je jednom osiguraniku izračunata mirovina iz II. stupa kao da će živjeti 93 godine! Večernji list 17. 10.2017.

${ }^{72}$ Ranije je dokumentiran gubitak u Agrokoru, potom treba vidjeti gubitak u Uljaniku, gdje je predsjednica nadzornog odbora bila iz mirovinskog osiguravajućeg društva.
} 
OMF-a posuđuje novac te plaćanjem kamata proizvodi gubitke. OMF-i su u državne obveznice do kraja 2016. godine uložili oko $73 \%$ imovine, to je činilo $21 \%$ javnog duga, a tu treba dodati i kamate, pa se taj udio povećava na $30 \%$ javnog duga ${ }^{73}$. Privatizacija javnog mirovinskog sustava doprinijela je prezaduženosti zemlje, a time su poskupjeli krediti za državu, tvrtke i za građane. Ulaganje novaca iz ostvarenih socijalnih prava - mirovina u državne obveznice proizvelo je dugoročne negativne učinke.
Troškove upravljanja istaknuo je Barr (2013.) kao rizik privatizacije. U Hrvatskoj do 2017. godine OMF-i su iskazali (tablica 1.) neto imovinu u iznosu od 91,9 milijardi kuna, a uplaćeni doprinosi su 67,6 milijardi kuna. Dakle, ostvarena razlika u vrijednosti je 24,3 milijardi kuna. Ukupne navedene naknade $^{75}$ su 3,9 milijardi kuna, što iznosi $5,8 \%$ u odnosu na uplaćene doprinose. $\mathrm{Na}$ godišnjoj razini za 2015. i 2016. naknade OMD-a činile su oko 7,5\% uplaćenih doprinosa po godini. Glede neto imovine po čla-

Tablica 1.

Uplaćeni doprinosi u II. stup, kamate na tranzicijski trošak, imovina OMF-a, naknade i dobit MOD-ova (2002. - 2017.)

\begin{tabular}{|c|c|c|c|c|c|c|c|c|c|c|c|}
\hline \multicolumn{10}{|c|}{ Ukupno naplaćene naknade (kumulativno, u mil. kn) } & \multicolumn{2}{|c|}{ Dobit (tis. kn) } \\
\hline \multirow[t]{2}{*}{$\begin{array}{l}\text { Raz- } \\
\text { doblje }\end{array}$} & \multirow[t]{2}{*}{$\begin{array}{l}\text { Upla- } \\
\text { ćeni } \\
\text { dopri- } \\
\text { nosi }\end{array}$} & $\begin{array}{l}\text { Iznos } \\
\text { kama- } \\
\text { te 5\% }\end{array}$ & $\begin{array}{l}\text { Iznos } \\
\text { kama- } \\
\text { te } 6 \%\end{array}$ & $\begin{array}{c}\text { Iznos }^{74} \\
\text { kamate } \\
\text { na ka- } \\
\text { mate } \\
5 \%\end{array}$ & $\begin{array}{c}\text { Iznos } \\
\text { kamate } \\
\text { na ka- } \\
\text { mate } \\
6 \% \\
\end{array}$ & \multirow[t]{2}{*}{$\begin{array}{c}\text { Neto } \\
\text { imovi- } \\
\text { na }\end{array}$} & \multirow[t]{2}{*}{$\begin{array}{l}\text { Uprav- } \\
\text { ljačke } \\
\text { na- } \\
\text { knade }\end{array}$} & \multirow[t]{2}{*}{$\begin{array}{l}\text { Ula- } \\
\text { zne } \\
\text { na- } \\
\text { kna- } \\
\text { de }\end{array}$} & \multirow[t]{2}{*}{$\begin{array}{l}\text { Uku- } \\
\text { pne } \\
\text { na- } \\
\text { kna- } \\
\text { de }\end{array}$} & \multirow[t]{2}{*}{$\begin{array}{l}\text { Dobit/ } \\
\text { gubitak } \\
\text { kumula- } \\
\text { tivno }\end{array}$} & \multirow[t]{2}{*}{$\begin{array}{c}\text { Dobit/ } \\
\text { gubitak } \\
\text { u poje- } \\
\text { dinoj } \\
\text { godini }\end{array}$} \\
\hline & & 0 , & 0 , & & & & & & & & \\
\hline 2002. & 28 & 0,096 & 0,116 & 0,0048 & 0,0 & & & & & & \\
\hline 2003. & 4 & & & & & & 38 & & & & \\
\hline 2004. & 67 & 0,358 & 43 & 0 & & & & & & & \\
\hline 2005. & 10,29 & 0 & 0,618 & & & 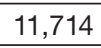 & & & & & \\
\hline 2006. & 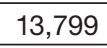 & & 0,828 & & & & & & & & \\
\hline 2007. & 81 & 0,89 & 1,069 & 55 & 0,0 & 21 , & 5 & 1. & & & 011 \\
\hline 2008. & . & & & & & & & & & & 45 \\
\hline 2009. & 26,974 & 1,349 & 1,618 & 06745 & 0,0 & 29 & 7 & 182 & 143 & 72 & 591 \\
\hline 2010. & & & & & & & & & & & \\
\hline 2011. & 61 & 1,823 & 2,188 & 15 & 0, & 41 & 1,461 & 247 & 1,708 & 29 & 493 \\
\hline 2012. & & & 2,489 & & & & & 28 & & & 382 \\
\hline 2013. & 92 & 2,325 & 2,79 & 25 & 4 & 58 & 1,943 & 316 & 2,259 & 19 & 008 \\
\hline 2014. & & 2,5 & 3,082 & & & & & 35 & 2,6 & & 4,74 \\
\hline 2015. & 56,519 & 2,826 & 3,391 & 0,1413 & 0,20346 & 710 & 2,644 & 409 & 3,053 & 2190, & 199,224 \\
\hline 2016. & 6 & 3,093 & 3,711 & & 0,22266 & & & 462 & 3,500 & 2378 & 188,244 \\
\hline \multirow[t]{2}{*}{2017.} & 67,575 & 3,379 & 4,055 & 0,16895 & 0,2433 & 91,925 & 3,409 & 510 & 3,919 & 2585,217 & 206,5 \\
\hline & & 24,902 & 29,883 & 1,24515 & 79304 & & & & & & \\
\hline
\end{tabular}

Izvor: HANFA, izvješća za različite godine, autorov izračun kamata.

\footnotetext{
${ }^{73}$ Autor je bezuspješno tražio od Ministarstva financija i HANFE podatke o isplaćenim kamatama na emitirane državne obveznice.

${ }^{74} \mathrm{Za}$ isplatu kamata država se mora ponovno zaduživati pa je i to dio tranzicijskog troška.
} 
nu OMD-i za sebe su u 2016. zadržali 14\%, a ostalo je pripalo članu fonda ${ }^{76}$. Obvezna su mirovinska društva 2017. imala prihode od upravljanja 476,8 milijuna kuna, a rashoda od upravljanja OMF-a 133,6 milijuna kuna, što je više od tri i pol puta ${ }^{77}$. Ostvarena dobit za upravljanje fondovima u 2017. godini bila je 343,2 milijuna kuna. K tome, naknada mirovinskom osiguravajućem društvu plaća se kod prijenosa sredstava iz mirovinskog fonda u osiguravajuće mirovinsko društvo i od 2011. iznosi $5 \%$, a prije je bila $10 \%{ }^{78}$.

Rizik tranzicijskog troška bio je predmet osporavanja (Kraljević, 1998.; Bakić, 2017.). U spomenutoj strategiji zaključuje se da je u 2002. taj trošak bio oko $1,3 \%$ BDP-a te bi se do 2020. povećavao na oko $1,8 \%$ BDP-a. Poslije toga tranzicijski trošak bi se smanjivao i 2040. bio bi oko 0,5\% BDP-a. Analizirana strategija predviđa da se tranzicijski trošak pokriva iz proračuna, zaboravljajući što je o tome rekao dokument Svjetske banke (2000.).
Međutim, tranzicijskom trošku treba dodati: početne troškove reforme, kamate koje se plaćaju na državne obveznice i na druga zaduživanja, troškove obveznih mirovinskih društava te druge s tim povezane troškove. Jedna od mjera kojom se pokrivao povećani tranzicijski trošak, pored zaduživanja, bilo je povećanje PDV-a. Temeljem javno dostupnih podataka nije moguće precizno izračunati tranzicijski trošak, a računica u tablici 2. je izvjesna aproksimacija. $^{79}$

Tranzicijski trošak snose svi porezni obveznici i za njegovu visinu povećava se državni proračun (Samodol, 2014.). Time se socijaliziraju troškovi »privatizirane« štednje u II. stupu koju plaćaju svi porezni obveznici putem proračuna kao transmisijskog mehanizma nove međugeneracijske solidarnosti, a koristi, za sada, od toga ima samo mali broj osiguranika koji su imali velike plaće te primaju i mirovinu iz II. stupa.

${ }^{75}$ Nisu nam poznati iznosi naknada za banku skrbnika - depozitare kao ni naknade osiguravajućim mirovinskim društvima.

${ }^{76}$ Izračun temeljem ranije citiranog nalaza (Bađun i Klemenčić, 2011.: 6) u kojem je računato samo za aktivne članove, a ovdje se računa za sve članove kojih je 2016. godine bilo 1784 169, jer temeljem javno dostupnih podataka ne možemo doći do podatka za aktivne članove. Za 2016. oko $20 \%$ neaktivnih članova - bez uplata i time bi udio OMD-a u zadržanoj dobiti bio veći od $14 \%$ za sve članove.

${ }^{77}$ Međutim, kod rashoda od upravljanja fondom najveća je stavka ostali troškovi od upravljanja fondom i ona je 2016. iznosila 74,6 milijuna, odnosno $64 \%$, a 2017. povećala se na 89,5 milijuna. Dodatnim istraživanjima trebalo bi ustanoviti o kakvim se »ostalim« troškovima radi.

${ }^{78}$ Ovakve promjene iznosa više izgledaju na marketinško licitiranje nego pažljivo umjeravanje.

${ }^{79}$ Tražeći sredstva u Predstavništvu Europske komisije u Hrvatskoj kojim bi, uz pretpostavku raspoloživosti potrebnih podataka, interdisciplinarni tim obavio odgovarajuću analizu održivosti II. stupa, posebno računice tranzicijskog troška, autor je informiran kako je Hrvatska vlada za tu svrhu dobila sredstva od EU-a u drugoj polovici 2017. godine. Resorno je ministarstvo na upit najavilo raspisivanje natječaja, a posao je dobila tvrtka Beier Research \& Edward Palmer Consulting. Rezultati njihovog istraživanja predstavljeni su povlaštenoj skupini stručnjaka, a projekt su proveli Ole Beier Sørensen i Edward Palmer, dansko-švedski tim. Što se tiče II. stupa, isporučena studija je u skladu s interesima hrvatske mirovinske industrije, a uopće se ne bavi trazicijskim troškom, rizikom ulaganja u dionice, kao ni upravljačkim troškovima. Autor ovog teksta obratio se ovoj dvojici stručnjaka, međutim, oni su odbili odgovoriti na gornja pitanja glede II. stupa. Svakako, njihove isporuke zaslužuju osvrt u domaćoj i stranoj periodici. 
Tablica 2.

Cijena koštanja »prinosa« OMF-a

\begin{tabular}{l}
\hline $\begin{array}{l}\text { Plaćene ulazne naknade } \\
\text { društvima za upravljanje, }\end{array}$ \\
Tablica 1.
\end{tabular}

Tablica 1.

Plaćene upravljačke naknade

društvima za upravljanje,

3.409 .000 .000

Tablica 1.

Kredit Svjetske banke, početni 200.000 .000
trošak

Kamate na uplaćene doprinose

- državni dug za pokriće

tranzicijskog troška od 67,6

29.883.000.000

milijardi (računato po stopi $6 \%$

godišnje), Tablica 1.

Kamate na kamate po stopi od

$6 \%$, Tablica 1.

1.793 .040 .000

Ukupno

35.795 .040 .000

Napomena: iznosi su zaokruženi radi lakšeg izračuna.

Dakle, u tablici 2. daje se izračun tranzicijskog troška pod pretpostavkom računanja kamata na uplaćene doprinose u II. stup, kao na javni dug, po stopi $6 \%$ godišnje, kao i kamate na kamate, a tu su pribrojeni troškovi naknada i kredita Svjetske banke. Višak neto imovine OMF-a u odnosu na uplaćene doprinose u II. stup (tablica 1.) iznosi 24,3 milijardi kuna. Međutim, za ove »prinose« plaćena je previsoka cijena i ona za 11,5 milijardi premašuje vrijednost neto imovine.

Ovo je ključni argument provedene evaluacije koja govori o neodrživosti tranzicijskog troška koji je pojeo ostvarene »prinose«, kao i zaključka o nužnosti demontaže obveznosti štednje u II. stupu.

\section{ZAKLJUČAK}

Proces privatizacije mirovina u Hrvatskoj dio je globaliziranog projekta koji je provodila Svjetska banka i lokalni dionici koji nisu vlasnici te reforme. Proces i dije- lom učinci privatizacije uvelike su usporedivi s ostalim, posebno srednjoeuropskim tranzicijskim zemljama.

Tranzicijske zemlje, posebno Poljska, Slovačka i Mađarska, u doba gospodarske krize 2008. godine stavile su na dnevni red javnih rasprava pitanja održivosti II. stupa. Proces privatizacije mirovinskog sustava kroz II. stup pokazao se neodrživim za javne financije. Obvezni mirovinski fondovi dominantno su ulagali u državne obveznice, dakle u javni dug, mirovine koje su počeli isplaćivati bile su manje od planiranih, a troškovi upravljanja previsoki. Vlade ovih zemalja nisu pristale na daljnja zaduživanja i povećanja poreza kako bi se predfinancirao projekt, odnosno rastao tranzicijski trošak. Ukidanje obveznosti članstva u II. stupu bio je značajan doprinos ozdravljenju javnih financija te boljeg nošenja s krizom ili bržeg izlaska iz nje.

Dakle, na razini zemalja višegradske skupine, s tim da Češka nije uvela obvezni II. stup, u području mirovina na djelu su procesi konvergencije. Važno je istaknuti da su ostale EU tranzicijske članice znatno redefinirale II. stup ili ga učinile dobrovoljnim.

Analize i rasprave te donesene odluke u ovim zemljama svakako su inspirativan poticaj evaluacije dijela učinaka II. stupa u Hrvatskoj. U tom smislu, razlikuje se više autoritarna mađarska, od demokratske poljske i slovačke prakse.

Hrvatska u vrijeme donesenih odluka u ostalim tranzicijskih zemljama nije bila članicom EU-a, pa nije dijelila iskustvo rasprava i reakcija koji su dolazili s EU razine. O tim raspravama i donesenim odlukama nije bila informirana niti hrvatska javnost, gdje su mediji u službi financijske industrije.

U Hrvatskoj se ne provodi monitoring ${ }^{80}$ i evaluacija učinaka privatizacije mirovin-

${ }^{80}$ Od 2019. godine HANFA je započela očito s novom praksom »monitoringa« II. stupa, pa je na press konferenciji rečeno da će najveći izazov svakako biti utjecaj očekivanog rasta kamatnih stopa, koji utječe na smanjenje cijena obveznica, a koje u ukupnoj strukturi čine značajan dio imovine mirovinskih fondova (HANFA, 2019.). O tranzicijskom trošku, odnosno koliko ovaj projekt košta javne financije nije bilo riječi. 
skog sustava u II. stupu. K tome, ne koristi se pojam privatizacija s kojim građani imaju loše iskustvo, već pojam kapitalizacija. Ne koristi se ni pojam predfinanciranje kao ključna okosnica ovog projekta. Ovi se pojmovi ne koriste niti u znanstvenom diskursu.

Mirovinski sustav i njegova privatizacija nisu u dovoljnoj mjeri bile istraživačke teme hrvatske akademske zajednice. Provedene analize ne tematiziraju ključne probleme $\mathrm{i}$ izazove, to jest, ostvarivanje ciljeva reformi, troškove upravljanja i održivost tranzicijskog troška (Nestić i sur., 2011.; Bejaković, 2016.). U medijima ne postoje pretpostavke za zauzeti i argumentirani javni diskurs.

Planirano pokrivanje tranzicijskoga troška smanjenom mirovinom u I. stupu od 4 do $27 \%$ pokazalo se socijalno i politički neodrživim. Mirovinski dodatak ispravio je zdravoj logici neprihvatljivu odredbu reforme i ukazao na loše pripremljenu reformu.

Povratak beneficiranih osiguranika $\mathrm{u}$ prvi stup te povratak najvećeg broja dragovoljnih drugostupaša u I. stup govore o promašajima reforme i financijskim gubicima koji se tek trebaju izračunati.

Privatizacija mirovina trebala je razviti tržište kapitala, međutim, tržište kapitala u doba krize je slomljeno i nije se još oporavilo. Od vremena krize pa do slučaja Agrokora nisu se analizirali gubitci supstance u OMF-ima, kao ni nepoštena praksa spašavanja plasmana banaka vlasnica koja je generirala gubitke.

Analiza troškova na razini godišnjih naknada, do sada akumuliranog dobitka OMD-a te udjela troškova u strukturi dobiti po članu govori o neodrživosti sustava. Tako veliki operativni troškovi doveli su u pitanje pozitivno poslovanje i prinose OMF-a te održivost javnih financija.

U okolnostima nerazvijenog tržišta kapitala OMF-a dominantno ulažu u državne obveznice, odnosno u javni dug te dovode $\mathrm{u}$ pitanje kreditni rejting zemlje. U analizi je pokazano kako ova ulaganja gdje država sama sebi posuđuje novac uz provizije i kamate ne može biti održiv i ne može dati pozitivne prinose. Rast ulaganja u državne obveznice prijetnja je argentinskim sindromom.

Vlada ne prati rast tranzicijskog troška već za pokrivanje istog povećava PDV i zadužuje se. Time se jača porezna presija i slabi se gospodarski razvoj. Tranzicijski je trošak pojeo prinose OMF-a i ugrozio javne financije. Zbog toga je zemlja sporije izašla iz krize, a onda se manje ulaže u prevažne sektore obrazovanja, znanosti i kulture. Demografska kriza baca novo svjetlo na neodrživost privatiziranog hrvatskog mirovinskog sustava. U tom smislu, evaluacija daje argumente za demontažu obveznosti drugog stupa i konvergenciju mirovinskog sustava sa zemljama višegradske skupine.

Privatizacija mirovina nije novim ulaganjima potaknula investicije, zapošljavanja i rast. On je doprinos produbljenju krize i seljenja mlađih naraštaja u inozemstvo.

Dodatnim analizama trebalo bi empirijski potkrijepiti tezu koja proizlazi iz ove analize, da je zbog tranzicijskog troška II. stupa i njegovih gubitaka Vlada, u reformi 2018. godine, bila primorana na podizanje dobi za odlazak u mirovinu te na dodatno penaliziranje prijevremenog umirovljenja. To se kvalificira kao negativni ishod privatizacije javnog mirovinskog sustava.

Analiza je pokazala niz promašaja u privatizaciji javnog mirovinskog sustava, a u slučaju nepoduzimanja odgovarajućih mjera sličnih drugim tranzicijskim zemljama Hrvatska će se suočiti s ishodima reforme sličnim u Čileu.

Provedena reforma uz kolonijalni mandat Svjetske banke i koristi financijske industrije govori o nedostatku civilizacijskih kompetencija ${ }^{81}$ da se sobom upravlja.

\footnotetext{
${ }^{81} \mathrm{O}$ teoriji civilizacijskih nekompetencija i njezinoj interpretaciji vidjeti u Bežovan i Matančević (2017.)
} 
Država nema sposobne institucije koje bi trebale provoditi monitoring i evaluaciju ovog projekta. Ovaj se fenomen objašnjava ovisnošću o prijeđenom putu (eng. path dependency). Očito, nad Hrvatskom i dalje lebdi duh mađarskog državnika Deaka Ferenca i nemogućnost revizije financijskog dijela Hrvatsko-ugarske nagodbe. Još uvijek zvone njegove proročke riječi upućene hrvatskim pregovaračima da »(...) ona zemlja, koja nema samostalnih financija, samo životari, pa da nije pravo, da Hrvatska ostane do vijeka pod tuđim tutorstvom.« (Matković, 2011.: 29). U ovaj kontekst dobro se uklapa i Krležina rugalica: »Dođite i vladajte nad nama jer smo nesposobni da sami sobom upravljamo.« (Krleža, 1937.).

Mirovinski sustav, kao i neki drugi sustavi socijalne politike u Hrvatskoj, nedovoljno je istražen i nedostaju empirijski pokazatelji te njihova analiza kao podloga za vođenje politike. Za područje istraživanja mirovinskog sustava javni instituti društvenih znanosti morali bi imati precizne višegodišnje naloge. To može biti podloga za vođenje politike utemeljene na empirijskim dokazima, a i za argumentirane rasprave u javnosti.

\section{LITERATURA}

Adascalitei, D., \& Domonkos, S. (2018). Learn from the neighbour: Emulation and learning in Easter European mandatory private pensions reforms, In A. Batory, A. Cartwright \& D. Stone (Eds), Policy Experiments, Failures and Innovations - Beyond Accession in Central and Eastern Europe (pp. 45-65). Cheltenham: Edvard Elgar.

Anušić, Z. (1998). Rasprava. Revija za socijalnu politiku, 5(2-3), 153-173. https://doi.org/10.3935/ rsp.v5i2.349

AZ Obvezni mirovinski fond, Erste plavi mirovinski fond, Obvezni mirovinski fondovi PBZ Croatia osiguranje \& Raiffeisen mirovinski fondovi. (2017). Izvještaj o radu obveznih mirovinskih fondova za 2016. godinu.

Bađun, M., \& Klemenčić. I. (2011). Troškovi upravljanja institucija I. i II. stupa mirovinskog osiguranja. Dostupno na http://www.ijf.hr/upload/ files/file/newsletter/63.pdf
Bakić, D. (2000). Drugi i treći stup novoga hrvatskog mirovinskog sustava: napomene i pitanja. Financijska teorija i praksa, 24(2), 189-213.

Bakić, D. (2017). Intervju.

Barr, N. (1994). Income transfers: Social insurance. In N. Barr (Ed.), Labour Markets and Social Policy in Central and Eastern Europe - The Transition and Beyond (pp. 208-218). New York: Oxford University Press.

Barr, N. (2002). Mirovinske reforme: mitovi, istine i strategijski izbori. Revija za socijalnu politiku, 9(3-4), 343-364. https://doi.org/10.3935/rsp. v9i3.160

Barr, N. (2013). Designing pensions: What can we learn from economic theory? What policy directions? 11 $1^{\text {th }}$ Annual Network for European Social Policy Analysis ESPAnet Conference on Social Policy and Economic Development, Poznań. 5-7 September.

Barr, N., \& Diamond, P. (2009). Reforming pensions: Principles, analytical errors and policy directions. International Social Security Review, 62(2), 5-29. https://doi.org/10.1111/j.1468246X.2009.01327.x

Barr, N., \& Diamond, P. (2016). Reforming pensions in Chile, Polityka Społeczna, (1), 4-9. Available at https://economics.mit.edu/files/12427

Barr, N., \& Harbison, R. W. (1994). Overview: Hopes, tears and transformation. In N. Barr (Ed.), Labour Markets and Social Policy in Central and Eastern Europe - The Transition and Beyond (pp. 1-28). New York: Oxford University Press.

Baturina, D. (2016). Utjecaj trećeg sektora na socio-ekonomski razvoj Republike Hrvatske (doktorska disertacija). Zagreb: Pravni fakultet Sveučilišta u Zagrebu.

Bejaković, P. (2014). Zašto ne treba ukinuti drugi stup. Posjećeno 15. travnja 2014. na mrežnim stranicama www.banka.hr

Bejaković, P. (2016). Zašto treba održati drugi mirovinski stup. Radno pravo, (2), 63-67.

Bežovan, G. (2014a). Hrvatska treba krenuti poljskim putem! Posjećeno 15. travnja 2014. na mrežnim stranicama www.banka.hr

Bežovan, G. (2014b). Hrvatska ipak krenula putem Poljske. Posjećeno 15. travnja 2014. na mrežnim stranicama www.banka.hr

Bežovan, G., \& Matančević, J. (2017). Civilno društvo i pozitivne promjene. Zagreb: Školska knjiga.

Bielawska, K., Chłoń-Domińczak, A., \& Stańko, D. (2015). Retreat from mandatory pension funds in countries of the Eastern and Central Europe in result of financial and fiscal crisis: 
Causes, effects and recommendations for fiscal rules. Available at https://ssl-uczelnia.sgh.waw. pl/pl/uczelnia/badania/grupy_badawcze/ppg/ Documents/Badania\%20naukowe/Report\%20 CEE\%20reversals\%20-\%20final_afterJPEF.pdf

Bohle, D., \& Greskovits, B. (2012). Capitalist diversity on Europe's periphery. Ithaca, NY: Cornell University Press.

Bošković, R., (2017). Slom Hrvatske 2009. : tko je kriv za 6 godina depresije i izgubljenih 200 tisuća radnih mjesta i 500 milijardi kuna. Zagreb: Prometheus - moderni mediji.

Brčić, S. (1994). Preobrazba socijalnog osiguranja u uvjetima slobodnog tržišnog gospodarstva nužnost preobrazbe mirovinskog osiguranja. Fonogram konferencije.

Bulaš, I. (1998). Rasprava. Revija za socijalnu politiku, 5(2-3), 153-173. https://doi.org/10.3935/ rsp.v5i2.349

Cerami, A. (2006). Social policy in Central and Eastern Europe - The emergence of a new European welfare regime. Berlin: LIT Verlag.

Chambers, D. E., Wedel, K. R., \& Rodwell, M. K. (1992). Evaluating social programs. Needham Heights: Allyn and Bacon.

Cousins, M. (2005). European Welfare States. London: Sage.

Čavrak. V. (2016). Dugoročna održivost drugog mirovinskog stupa?. Ekonomija/Economics, 23(1), 39-54.

Datz, G., \& Dancsi, K. (2013). The Politics of pension reform reversal: A comparative analysis of Hungary and Argentina. East European Politics, 29(1), 83-100. https://doi.org/10.1080/215991 65.2012 .759940

Dnevno. (5. 1. 2018). Ova zemlja ima više prijatelja u svijet nego doma-Ekonomski institut podržava genocidni II. mirovinski stup.

Esping-Andersen, G. (1999). Social foundations of postindustrial economies. Oxford: Oxford University Press.

European Commission. (2001). Reforms of pension systems in the EU: An analysis of the policy options. European Economy. Available at http:// ec.europa.eu/economy_finance/publications/ pages/publication7985_en.pdf

Financial Times. (2014). Poland plays with fire over pension reform. Available at https://www.ft.com/ content/ac8221f4-88e3-11e3-9f48-00144feab7de

Fultz, E. (2012). The retrenchment of second-tier pensions in Hungary and Poland: a precautionary tale. International Social Security Review, 65(3), 1-25. https://doi.org/10.1111/j.1468246X.2012.01434.x
Globus, (12. 2. 2014). Velika mirovinska laž.

Golinowska, S., \& Żukowski, M., (2011). The impact of the economic and financial crisis on the Polish pension system. Zeitschrift für Sozialreform, 57(3), 267-285. https://doi.org/10.1515/ zsr-2011-0304

Grbavac, D. (2014). Promjenama u II. stupu Vlada ispravlja greške u sustavu. Posjećeno 15. travnja 2014. na mrežnim stranicama www.banka.hr

Greve, B. (2017). Introduction: Evaluation as an instrument in social policy. In B. Greve (Ed.), Handbook of Social Policy Evaluation (pp. 1-12). Cheltenham: Edward Elgar Publishing.

Guardiancich, I. (2007). Politička ekonomija mirovinskih sustava u Hrvatskoj 1991.-2006. Financijska teorija i praksa, 31(2), 89-150.

Hrvatska agencija za nadzor financijskih usluga. (2016). Godišnje izvješće 2016. Dostupno na www.hanfa.hr.

Hrvatska agencija za nadzor financijskih usluga. (2017). Godišnje izvješće 2017. Dostupno na www.hanfa.hr.

Hrvatska agencija za nadzor financijskih usluga. (2018). Hrvatski sabor, Odbor za financije $i$ državni proračun. Odgovor na pitanje, 19. 1istopada 2018.

Hrvatska agencija za nadzor financijskih usluga. (2019). Obvezni mirovinski fondovi - veliki sustav s potencijalnom daljnjeg rasta. Priopćenje za javnost, 1. veljače 2019.

Hansen, M. B., Breidahl, K. N., Furubo, J. E., \& Halvorsen, A. (2017). Eight attention points when evaluating large-scale public-sector reforms. In B. Greve (Ed.), Handbook of Social Policy Evaluation (pp. 471). Cheltenham: Edward Elgar Publishing.

Havel, V. (1994). Foreword. In N. Barr (Ed.), Labour Markets and Social Policy in Central and Eastern Europe - The Transition and Beyond (pp. XIII-XIV). New York: Oxford University Press.

Heubeck, K. (1994). Preobrazba socijalnog osiguranja u uvjetima slobodnog tržišnog gospodarstva nužnost preobrazbe mirovinskog osiguranja. Fonogram konferencije održane 10.-11. prosinca 1994.

Holzmann, R., \& Guven, U. (2009). Adequacy of retirement income after pension reforms in Central, Eastern, and Southern Europe: Eight country studies. Washington, DC: World Bank.

Holzman, R., \& Hinz, R. (2005). Old-age income support in the 21st century: An international perspective on pension systems and reform. Washington, DC: World Bank. 
Holzmann, R., MacKellar, L. \& Repansek, J. (Eds.). (2009). Pension reform in Southeastern Europe: Linking to Labor and Financial Market Reforms. Washington, DC: World Bank.

Hrvatski državni sabor. (1999). Fonogram rasprave prilikom usvajanja Konačnog prijedloga Zakona o obveznim i dobrovoljnim mirovinskim fondovima. Materijal dobiven po zahtjevu od nadležne službe 2017. godine.

Inglot, T. (2016). Path-dependency versus reform in pensions and family policy re-examined: Dual trajectories of the Polish welfare state since the 1990s. Social Policy \& Administration, 50(2), 241-261. https://doi.org/10.1111/spol.12213

Jakovčević, D., \& Bežovan, G. (10.10.2018). Zašto je II. mirovinski stup neodrživ. Večernji list.

Jutarnji list. (7.10.2016). Osim HEP-a i HAC-a, zanimaju nas i ACI te Janaf, kao i zračne luke.

Jutarnji list. (1. 3.2017). Vlada uvodi dječji dohodak.

Jutarnji list. (21. 9.2017). Vlada koja takne 27\% dodatka na mirovine mora otići s vlasti.

Jutarnji list. (2. 10. 2017). Još rade izračune kako skresati sve buduće mirovine.

Jutarnji list. (21. 10.2017). Udruge umirovljenika iz. zablude napadaju drugi mirovinski stup.

Jutarnji list. (25. 10. 2018). Budućnost mirovinskog sustava - Dodatak bi za sve trebao biti jednak.

Kraljević, H. (1998). Rasprava. Revija za socijalnu politiku 5(2-3), 153-173. https://doi.org/10.3935/ rsp.v5i2.349

Krleža, M. (1937). Deset krvavih godina. Zagreb.

Krzyzak, K. (2015a). Slovakia's second-pillar pension system under threat again. Available at https://www.ipe.com/countries/cee/slovakias-second-pillar-pension-system-under-threat-again/10006347.fullarticle

Krzyzak, K. (2015b). Slovakia's second-pillar pension system faces another exodus. Available at https://www.ipe.com/countries/cee/slovakias-second-pillar-pension-system-under-threat-again/10006347.fullarticle

Krzyzak, K. (2017). Poland: Dismantling the second pillar. Available at https://www.ipe.com/ countries/cee/slovakias-second-pillar-pension-system-under-threat-again/10006347.fullarticle

Marušić, Lj., \& Škember, A. (2008). Socijalni i gospodarski aspekti uvođenja obveznog mirovinskog osiguranja na temelju individualne kapitalizirane štednje. Revija za socijalnu politiku, 15(3), 343-363. https://doi.org/10.3935/ rsp.v15i3.779
Matković G. (2016). Mirovinski sustav Srbije u svjetlu krize. Revija za socijalnu politiku, 23(1), 99119. https://doi.org/10.3935/rsp.v23i1.1272

Matković, S. (2011). Josip Frank i kritika financijskog dijela Hrvatsko-ugarske nagodbe. PILAR - Časopis za društvene $i$ humanističke studije, 6(11), 27-34. https://hrcak.srce.hr/72598

Müller, K. (1999). The political economy of pension reform in Central-Eastern Europe. Cheltenham: Edward Elgar.

Müller, K. (2002). Strukturalne mirovinske reforme u tranzicijkim zemljama: Politički sudionici i uloga države. Financijska teorija i praksa, 26(2), 387-404.

Naczyk, M. (2016). Poland's experiment with multi-pillar pensions: From success story to failure. Prijevod na engleski dobiven od autora.

Naczyk, M., \& Domonkos, S. (2016). The financial crisis and varieties of pension privatization reversals in Eastern Europe. Governance: An International Journal of Policy, Administration, and Institutions, 29(2), 167-184. https://doi. org/10.1111/gove.12159

Nestić, D., Potočnjak, Ž., Puljiz, V., Rašić Bakarić, I., Švaljek, S., Tomić, I., Vehovec, M., \& Vukorepa, I. (2011). Izazovi i mogućnosti za ostvarenje primjerenih starosnih mirovina u Hrvatskoj. Zagreb: Ekonomski institut.

Novi list. (10. 2. 2012). PDV 25 posto, turizmu 10 posto od iduće godine.

Njavro, Đ. (1994). Preobrazba socijalnog osiguranja u uvjetima slobodnog tržišnog gospodarstva nužnost preobrazbe mirovinskog osiguranja. Fonogram konferencije.

Odluka o izmjenama i dopunama Odluke o osnivanju Povjerenstva za mirovinsku reformu. Narodne novine, br. 102/1998.

Odluka o osnivanju Povjerenstva za mirovinsku reformu. Narodne novine, br. 27/1998.

Orenstein, M. A. (2009). Transnational actors in Central and East European pension reforms. In A. Cerami \& P. Vanhuysse (Eds.), Post-Communist Welfare Pathways - Theorizing Social Policy Transformations in Central and Eastern Europe (pp. 133). Basingstoke: Palgrave Macmillan.

Orenstein, M. A. (2013). Pension privatization: Evolution of a paradigm. Governance: An International Journal of Policy, Administration, and Institutions, 26(2), 259-281. https://doi.org/10.1111/ gove. 12024

Orszag, P. E. \& Stiglitz, J. E. (1999). Rethinking pension reforms: Ten myths about social security systems. Washington, DC: World Bank. 
Ortiz, I., Durán-Valverde, F., Urban, S., \& Wodsak, V. (Eds). (2018). Reversing Pension Privatizations: Rebuilding public pension systems in Eastern Europe and Latin America, Geneva: International Labour Organisation.

Ott, K. (2014). S drugim stupom oprezno!. Posjećeno 15. travnja 2014. na mrežnim stranicama www.banka.hr

Potočnjak, Ž. (2000) Nove mirovinske formule mirovinskog osiguranja generacijske solidarnosti. Revija za socijalnu politiku, 7(1), 1-18. https:// doi.org/10.3935/rsp.v7i1.266

Potočnjak, Ž. (2014). Trebamo li budućim generacijama ostaviti samo dugove. Posjećeno 15. travnja 2014. na mrežnim stranicama www.banka.hr

Puljiz, V. (1998). Kriza i reforme mirovinskih sustava. Revija za socijalnu politiku, 5(2-3), 125-129. https://doi.org/10.3935/rsp.v5i2.339

Queisser, M. (1994). Preobrazba socijalnog osiguranja u uvjetima slobodnog tržišnog gospodarstva nužnost preobrazbe mirovinskog osiguranja. Fonogram konferencije održane 10.-11. prosinca 1994.

Revija za socijalnu politiku. (1998). Rasprava. Revija za socijalnu politiku, 5(2-3), 153-173. https://doi. org/10.3935/rsp.v5i2.349

Rohatinski, Ž. (2015). Ogledi u realnom vremenu (2000.-2014.). Zagreb: Jutarnji list.

Samodol, A. (2000). Reforma mirovinskog sustava ili reforma financijskog tržišta. Financijska teorija i praksa, 24(3), 383-394.

Samodol, A. (2014). Analiza fiskalnih i demografskih razloga za provedbu mirovinske reforme $\mathrm{u} \mathrm{Hr}$ vatskoj od 2002. do 2012/13. Rukopis.

Schneider, O. (2012). Pension systems in the Visegrad Group - Different solutions to the same problem. Available at http://visegradrevue.eu/ pension-systems-in-the-visegrad-group-different-solutions-to-the-same-problem/

Simonovits, A. (2011a). The mandatory private pension pillar in Hungary: An obituary. International Social Security Review, 64(3), 81-98. https:/doi. org/10.1111/j.1468-246X.2011.01404.x

Simonovits, A. (2011b). Impact of the economic and financial crisis on pension systems in Central and Eastern Europe: Hungary. Zeitschrift für Sozialreform, 57(3), 287-298. https://doi.org/10.1515/ zsr-2011-0305

Stanovnik, T. (2000) Mirovinski sustav i mirovinska reforma u Sloveniji. Financijska teorija i praksa, 24(3), 329-341.

Stockmann, R. (2011). An introduction to evaluation. In R. Stockmann (Ed.), A Practitioner Han- dbook on Evaluation (pp. 13-61). Cheltenham: Edward Elgar.

Strategija razvitka Republike Hrvatske "Hrvatska u 21. stoljeću" - Strategija razvitka mirovinskog sustava i sustava socijalne skrbi. Narodne novine, br. 97/2003.

Svjetska banka. (1995). Svjetska banka: prijedlog reforme hrvatskog mirovinskog sustava. Revija za socijalnu politiku, 2(4), 315-322. https://doi. org/10.3935/rsp.v2i4.506

Svjetska banka. (1997). Financiranje javnog sektora. reforma zdravstva i mirovinska reforma u Hrvatskoj. Revija za socijalnu politiku, 4(3), 265-285. https://doi.org/10.3935/rsp.v4i3.386

Svjetska banka. (2000). Mirovinska reforma u Hrvatskoj. Revija za socijalnu politiku, 7(2), 163-173. https://doi.org/10.3935/rsp.v7i2.257

Szczepański, M. (2016). The impact of Polish pension reform on present and anticipated conditions of public finance. Economy \& Business, 10, 46-54. Available at https://www.scientific-publications. net/get/1000019/1462625517140326.pdf

Šimović. H. (2014). Ukidanje drugog stupa je prvi čavao u lijes mladog čovjeka. Posjećeno 15. travnja 2014. na mrežnim stranicama www.banka.hr

Škember, A. (1994). Preobrazba socijalnog osiguranja u uvjetima slobodnog tržišnog gospodarstva nužnost preobrazbe mirovinskog osiguranja. Fonogram konferencije.

Škember, A. (1998). Hrvatska mirovinska reforma: tijek i dvojbe. Revija za socijalnu politiku, 5(23), 139-147. https://doi.org/10.3935/rsp.v5i2.347

Škember, A. (2000). Kriza i reforma mirovinskog sustava na tri oslonca. Financijska teorija i praksa, 24(3), 439-454.

Škember, A. (2017). Neka pitanja vezana uz II. stup mirovinskog osiguranja. Okrugli stol, Zagreb, 28. ožujka 2017., II. Mirovinski stup - za i protiv.

Šonje, V. (2014a). Drugi mirovinski stup u kratkom $i$ dugom roku. Posjećeno 15. travnja 2014. na mrežnim stranicama www.banka.hr

Šonje, V. (2014b). Referendum: Što ako odlučimo srušiti drugi stup?. Posjećeno 15. travnja 2014. na mrežnim stranicama www.banka.hr

Štimac, D. (28. 9. 2018). Sve što treba znati o drugom stupu. Večernji list.

Udruženje društava za upravljanje mirovinskim fondovima i mirovinskih osiguravajućih društava. (2011). Mirovinska reforma u Republici Hrvatskoj - Dosadašnji učinci, aktualno stanje i prijedlozi za budućnost. Dostupno na http://mirovinskifondovi.hr/wp-content/uploads/2015/02/ Mirovinska-reforma-1.pdf 
Večernji list. (13. 6. 2012). Odvojio sam državu od mirovinskog sustava.

Večernji list. (30. 8. 2014). Zgranulo me što mirovinci $72,3 \%$ imovine drže u obveznicama $R H$, dakle u „smeću“.

Večernji list. (22. 10. 2016). Rođenim '62. i kasnije niže mirovine?.

Večernji list. (3. 11. 2016). Zbog 2. stupa daleko smo od eurozone i u rejtingu ,smeća“.

Večernji list. (10. 6. 2017). Ništa od sigurne starosti, mirovine bi se mogle uskoro pretvoriti u socijalnu ротоć.

Večernji list. (25. 8. 2017). U postojećim okolnostima nova ulaganja u Inu ne razmatramo.

Večernji list. (21. 9. 2017). Ne treba se vraćati unatrag i ukidati drugi stup, on nije izvor problema.

Večernji list. (27. 9. 2017). Padnu li mirovine, reforma nema smisla.

Večernji list. (21. 10. 2017). Kopecki: Drugi stup treba zaštititi Ustavom.

Večernji list. (21. 10. 2017). Paviću manje mirovine nisu diskriminacija, veće bi bile!?.

Večernji list. (2. 11. 2017). Novac članova u II. stupu predmet je nasljeđivanja.

Večernji list. (11. 11. 2017). Drugi je mirovinski stup opasno kockanje, svi su pobjegli osim Hrvatske.

Večernji list. (16. 11. 2017). „Hejterski“ o 2. stupu, opasno kockanje s akademskim ugledom.

Večernji list. (22. 11. 2017). Upravlja li zemljom Vlada ili mirovinski fondovi?.

Večernji list. (5. 1. 2018). Ekonomski smo neuspješni izato ne ide bez pokroviteljstva SAD-a ili Rusije.

Vedung, E. (2000). Public policy and program evaluation. Piscataway, NJ: Transaction Publishers.

Velculescu, D. (2011). Pension reforms in emerging europe: The uncertain road ahead. Conference: Pension Systems in Emerging Europe: reforms in the Age of Austerity, London. Ava- ilable at https://www.researchgate.net/publication/273134030

Vlada Republike Hrvatske. (2010). Program gospodarskog oporavka, travanj. Posjećeno 10. srpnja 2017. na https://vlada.gov.hr

Vlada Republike Hrvatske. (2015). Nacionalni program reformi 2015. Posjećeno 15. srpnja 2017. na https://vlada.gov.hr

Vukorepa, I. (2012). Mirovinski sustavi - kapitalno financirani mirovinski sustavi kao čimbenici socijalne sigurnosti. Zagreb: Pravni fakultet.

Vukorepa, I. (2018). Croatia: Government remains committed to second pension pillar in face of public debate. ESPN Flash Report 2018/12. Available at http://ec.europa.eu/social/main .jsp?catId $=1135 \&$ langId $=$ en\&newsId $=9065 \&$ moreDocuments $=$ yes\&tableName $=$ news

World Bank. (1994). Averting the old-age crisis. Washington, DC: World Bank.

World Bank. (2011). Croatia: Policy options for further pension system reform. Available at http:// siteresources.worldbank.org/INTCROATIA/ Resources/Croatia_Policy_Notes-Pension.pdf

Zakon o dodatku na mirovine ostvarene prema Zakonu o mirovinskom osiguranju. Narodne novine, br. 79/2007.

Zakon o hrvatskim braniteljima iz Domovinskog rata i članovima njihovih obitelji. Narodne novine, br. 121/2017.

Zakon o obveznim mirovinskim fondovima. Narodne novine, br. 19/2014.

Zakon o potvrđivanju ugovora između Republike Hrvatske i Bosne i Hercegovine o suradnji na području prava stradalnika rata u Bosni i Hercegovini koji su bili pripadnici Hrvatskog vijeća obrane i članova njihovih obitelji. Narodne novine, br. $2 / 2006$.

Zdunić, S. (1998). Mirovinska reforma i gospodarski razvoj. Revija za socijalnu politiku 5(2-3), 131137. https://doi.org/10.3935/rsp.v5i2.346 


\title{
Summary \\ EVALUATION OF THE PROCESS OF PENSION SYSTEM PRIVATIZATION IN CROATIA
}

\author{
Gojko Bežovan \\ Department of Social Work, Faculty of Law, University of Zagreb \\ Zagreb, Croatia
}

In 2002 Croatia implemented a radical pension system reform through privatization of a part of the public system, the so-called second pillar of defined contributions and the introduction of the third voluntary pillar. The reform was implemented according to the World Bank model, similarly as in other countries in transition. Unlike other countries in transition, the Croatian system survived the crisis and no other significant additional reform was undertaken in it.

The text analyses the use and need of conducting an evaluation of such comprehensive reforms as a policy development based on evidence. In that context, the paper examines pension reforms in the Visegrád Group countries (Poland, Slovakia and Hungary) where the mandatory participation in the second pillar was cancelled due to the crisis. With regard to pension reform policies, these countries are undergoing a convergence process.

Discussions about the pension system privatization date back to the first part of the 1990 s, and the introduction of the mandatory second pillar opened debates about the capital market development, stimulation of economic growth, new employment and larger pensions. Although there were some political plans to temporarily halt payments to the second pillar, it survived the crisis. Faced with the pensions from the first and second pillars for voluntary second tier participants that were smaller than the pensions from the first pillar only, the government gave an increase to the second tier participants returning to the first pillar. The 2018 reform provided a considerable part of the increase for the mandatory second tier participants. The public discourse analysis shows that main daily newspapers serve as a part of the media campaign of the mandatory pension funds, actually pension fund management companies, and there is no place for different opinions about the second pillar in them. The paper analyses the operative costs of pension fund management companies, dominant investments in government bonds which increases public debt and, bearing in mind publicly available data, the costs of transition.

Finally, pension reform aims are assessed against evaluation findings that point to the unsustainable second pillar and its reform similar to the reforms in aforementioned countries.

Key words: pension privatization, second pillar, countries in transition, Croatia. 